Portland State University

PDXScholar

\title{
To Die or Not to Die: an Examination of Gubernatorial Clemency Powers through a Case Analysis of Death Penalty Moratoriums
}

Mary Margaret L. Kirchner

Portland State University

Follow this and additional works at: https://pdxscholar.library.pdx.edu/honorstheses

Let us know how access to this document benefits you.

\section{Recommended Citation}

Kirchner, Mary Margaret L., "To Die or Not to Die: an Examination of Gubernatorial Clemency Powers through a Case Analysis of Death Penalty Moratoriums" (2018). University Honors Theses. Paper 605. https://doi.org/10.15760/honors.616

This Thesis is brought to you for free and open access. It has been accepted for inclusion in University Honors Theses by an authorized administrator of PDXScholar. Please contact us if we can make this document more accessible: pdxscholar@pdx.edu. 
Portland State University

PDXScholar

University Honors Theses

University Honors College

\section{To Die or Not to Die: An Examination of Gubernatorial Clemency Powers through a Case Analysis of Death Penalty Moratoriums}

Mary Margaret L. Kirchner

Let us know how access to this document benefits you.

Follow this and additional works at: https://pdxscholar.library.pdx.edu/honorstheses

This Thesis is brought to you for free and open access. It has been accepted for inclusion in University Honors Theses by an authorized administrator of PDXScholar. For more information, please contact pdxscholar@pdx.edu. 


\title{
To Die or Not to Die:
}

\section{An Examination of Gubernatorial Clemency Powers through a Case Analysis of Death Penalty Moratoriums}

\author{
By: \\ Meggie Kirchner \\ An undergraduate honors thesis in partial fulfillment of the degree of \\ Bachelor of Science \\ in \\ Political Science.
}

Thesis Advisor:

Phil Keisling

Portland State University 


\section{Table of Contents:}

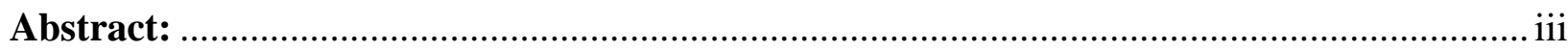

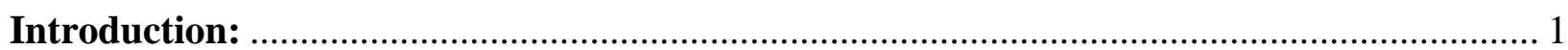

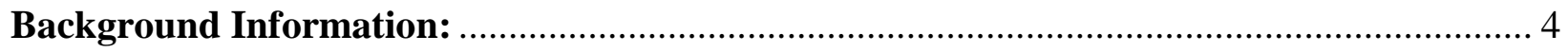

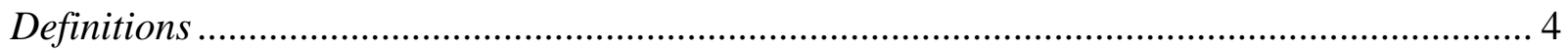

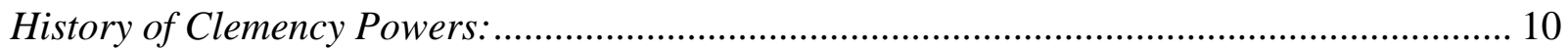

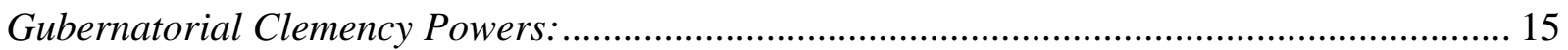

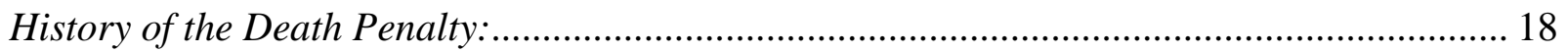

State History of the Death Penalty: ............................................................................ 20

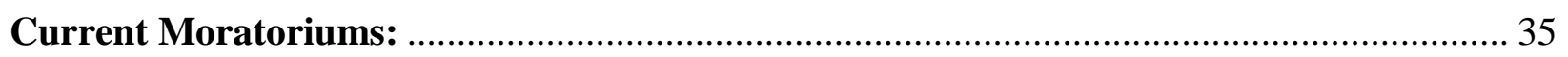

Summary of the Washington and Colorado Moratorium: .................................................. 36

Summary of Pennsylvania Moratorium and Commonwealth v. Williams (2015): ................. 47

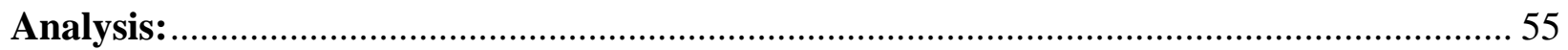

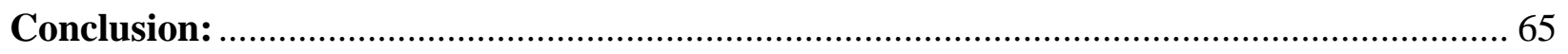

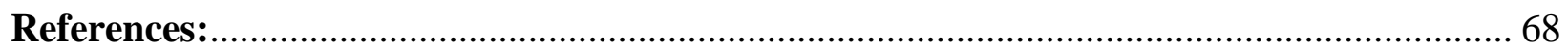




\begin{abstract}
:
Capital punishment is a controversial sentence reserved for the worst of the worst crimes. State citizens and legislatures have addressed the use of the death penalty in different ways. To mitigate capital punishment, governors have been granted the power to issue clemency for inmates in the criminal justice system. This clemency power is an essential component of the executive's ability to ensure checks and balances between the three branches of government. This report investigates the overlapping relationship between a governor's ability to affect the death penalty through acts of clemency. Four Governors in the United States have issued death penalty moratoriums in the recent years: Oregon Governor Kitzhaber in 2011, Colorado Governor Hickenlooper in 2013, Washington Governor Jay Inslee in 2014, and Pennsylvania Governor Tom Wolf in 2015. This analysis investigates the constitutional basis for governors' issuance of sweeping moratoriums to better understand the scope of gubernatorial clemency power. Furthermore, this investigation argues that these moratoriums are not an overreach of gubernatorial clemency powers and fall within the scope of clemency powers.
\end{abstract}




\section{Introduction:}

Citizens of the United States cannot agree on the use or abolition of the death penalty. Neither the President of the United States or Congress, nor the United States Supreme Court have taken any action to abolish the death penalty in modern times. As a result, state governments have been left to determine which side of the debate they fall. Federally, the death penalty has been in place since 1988 (“Federal Death Penalty | Death Penalty Information Center," 2018). Currently, nineteen states have matched the pattern of most of the western world and have abolished the death penalty ("States With and Without the Death Penalty|Death Penalty Information Center," 2018). Thirty-one states laws allow the death penalty to be used as a legal form of punishment ("States With and Without the Death Penalty $\mid$ Death Penalty Information Center," 2018). Four states have fallen somewhere in between as their citizens or legislatures have passed laws or constitutional amendments that allow the death penalty but their governors have questioned the legitimacy of the death penalty ("States With and Without the Death Penalty | Death Penalty Information Center,” 2018). This has, in the example of Colorado, Washington ${ }^{1}$, Oregon, and Pennsylvania, resulted in a "death penalty moratorium."

Through the executive powers granted in their state constitutions, Governor John Kitzhaber $^{2}$ and Governor Kate Brown of Oregon, Governor Tom Wolf of Pennsylvania, Governor Jay Inslee of Washington, and Governor John Hickenlooper of Colorado have issued moratoriums exercising their broad power to grant clemency in different forms such as pardons,

\footnotetext{
${ }^{1}$ As of February, 2018, the Washington State Senate voted to repeal the death penalty (Wasserman, 2018). The State House of Representatives has yet to vote on the bill and Governor Inslee has not signed the repeal into law.

${ }^{2}$ Governor Kitzhaber initiated this moratorium during his second stint as governor. Governor Kitzhaber served two terms as the Governor of Oregon from 1995 to 2003. Governor Kitzhaber was elected governor for a third time in 2011 and resigned early in his fourth term in 2015 (Sarasohn, 2018).
} 
reprieves, and commutations. Moratoriums are most similar to a governor's power to grant reprieves, however there are differences between the two. The power to grant clemency has been relatively unchecked both at the federal level and state level. Though there have been instances where the Supreme Court of the United States has reviewed the presidential power to grant clemency, and state supreme courts have reviewed individual governors' ability to grant clemency, there has not been any instance where the issuing of a death penalty moratorium has been deemed unconstitutional. Given the limited judicial review of these moratoriums, the question of how broad the governor's power to grant clemency is, specifically in instances of a moratorium, remains unanswered. Governors are able to issue these broad moratoriums because of their power to grant clemency and the lack of limits on this power. This analysis will examine, through the examples of the death penalty moratoriums in Oregon, Washington, Colorado, and Pennsylvania, how broad a governor's constitutional power is to grant clemency. This analysis will also explore what limits these powers have. Additionally, this analysis will distinguish the difference between pardons, reprieves, commutations, and moratoriums. Lastly, this analysis will investigate when a governor is legally allowed to issue these moratoriums and for what reasons.

The majority of crimes are dealt with at the state and local level ${ }^{3}$ which has resulted in the use of moratoriums at the state level. Federally, the death penalty has been in practice since 1988. Though the death penalty has been practiced since the birth of the United States as a nation, this analysis will focus on state issued moratoriums following the United States Supreme Court's decision in Gregg v. Georgia (1976) ${ }^{4}$. Gregg v. Georgia established the modern death

\footnotetext{
${ }^{3}$ State courts mainly handle criminal cases and other cases that deal with things such as wills and estates, whereas federal courts deal with issues that deal with the constitutionality of a law, policy, or action ("Comparing Federal \& State Courts," 2018).

${ }^{4}$ In 1976, the United States Supreme Court in Gregg v. Georgia (1976) determined that the bifurcated trial system and the weighing of mitigating and aggravating factors by a jury was a constitutional way of applying the death penalty (Gregg v. Georgia, 1976). There has to be an aggravating factor that makes the crime especially worse in
} 
penalty implemented in the United States. It is after Gregg v. Georgia that modern death penalty scholarship focuses.

Understanding why governors are able to use their power this broadly is important because of the factor that it adds to the debate on the death penalty. Governor Ryan of Illinois ${ }^{5}$ issued a death penalty moratorium when it was discovered that 12 people from Illinois' death row had been executed, but 13 other individuals had been exonerated from Illinois' death row (Chevigny \& Johnson, 2004). This moratorium was converted then to a blanket commutation by Governor Ryan for all 167 inmates on death row (Chevigny \& Johnson, 2004). Other states like Oregon, Washington, Colorado, and Pennsylvania have issued moratoriums for a variety of reasons. Washington's Governor Inslee issued the moratorium stating that it was to ensure that equal justice was being served in Washington's criminal justice system (Smith, 2014). Colorado's Governor Hickenlooper issued the moratorium because, he argued, of the imperfect and inequitable nature of Colorado's death penalty (Augé, Lee, \& Steffen, 2013). Pennsylvania's Governor Wolf issued the moratorium because, he believed the death penalty in Pennsylvania was “error-prone” and “expensive” (Hall, 2015). Oregon's Governor Kitzhaber issued the death penalty moratorium in 2011 , because he felt it was morally against his ethical position as a doctor $^{6}$ to execute inmates and because of he felt Oregon had an "unworkable" death penalty system (Jung, 2011). Similarly, Oregon's current Governor Kate Brown opted to continue the

comparison to other forms of homicide. This decision overturned the Court's decision in Furman v. Georgia (1972).

Furman v. Georgia in a plurality opinion deemed the death penalty unconstitutional because it was arbitrary and capricious (Furman v. Georgia, 1972).

${ }^{5}$ The Illinois death penalty will not be discussed in this analysis because it is no longer in effect and the death penalty is now abolished in Illinois ("States With and Without the Death Penalty | Death Penalty Information Center," 2018). The four moratoriums that are currently in place will be analyzed to investigate gubernatorial clemency powers.

${ }^{6}$ Governor Kitzhaber was a doctor before being elected as governor. As a doctor, Governor Kitzhaber swore to try and keep patients alive or heal them to the best of his abilities. Governor Kitzhaber in his press release stressed that executing individuals goes against his ethical and moral positions considering his background as a doctor and his quest to try and save lives whenever possible (Sarasohn, 2018). 
moratorium because she felt there are serious concerns with the constitutionality and workability of the Oregon capital system (Hernandez, 2016). These moratoriums act as a stay on the actual execution of the inmate, but do not alter the sentence the inmate originally received.

Checks and balances are engrained into the United States political system and are essential to the function of government at the federal and state level. The founding fathers fought and deliberated to ensure that no one branch of government could exceed the other two branches of government. Similar restrictions were integrated in each individual state constitution. Moratoriums can currently be interpreted as either an overreach by the executive branch - a step towards a more tyrannical future that our founders and revolutionaries fought to prevent - or, it can be seen as a means of ensuring that the checks and balances are truly being practiced. Others view a death penalty moratorium as part of a governor's power to grant clemency. Through the example governors issuing death penalty moratoriums, this paper will analyze the clemency powers granted to governors in Pennsylvania, Washington, Colorado, and Oregon and argue that these governors fall within their constitutionally-granted powers. This paper also analyzes the case law regarding governors issuing moratoriums through their reprieve powers and how these moratoriums enhance the checks and balances present in the United States governmental system. Lastly, this paper will argue why governors are constitutionally allowed to use their clemency power in broad terms.

\section{Background Information:}

\section{Definitions}

In order to understand why governors are constitutionally able to use their clemency powers to issue death penalty moratoriums, it is necessary to understand what makes a 
moratorium different from other traditional forms of clemency. Governors have the power to use clemency through the process of granting pardons, reprieves, and commutation ${ }^{7}$. More recently, these governors have used their clemency powers to issue what is often times called a moratorium by politicians or the media. In precise legal terms, these death penalty moratoriums actually are broad and expansive reprieves. Furthermore, Governor Kitzhaber, Governor Hickenlooper, and Governor Wolf all described the moratoriums issued as a reprieve although Governor Inslee referred to his actions as a death penalty moratorium. But what exactly is a moratorium and what distinguishes it from a pardon, reprieve, and commutation? The word moratorium is not mentioned in any state constitution or the federal constitution. So why then are these governors constitutionally allowed to use their explicit clemency powers for something not explicitly granted to them?

Clemency is defined, in the Merriam-Webster Law Dictionary, as either the "willingness or ability to moderate the severity of a punishment," or as "an act or instance of mercy, compassion, or forgiveness” (“Clemency | Definition of Clemency by Merriam-Webster Law Dictionary," 2018). Though there is a difference between pardons, reprieves, and commutations, they are all forms of clemency. Governors are given this clemency power through state constitutions. The Supreme Court of the United States has determined that each state is allowed to adopt its own form of clemency (Herrera v. Collins, 1993). Herrera v. Collins (1993) examined if the claim of actual innocence entitled a defendant to a federal habeas corpus relief. In the majority opinion, Chief Justice Rehnquist held that such a claim does not automatically

\footnotetext{
${ }^{7}$ In Oregon, the Governor's power to grant clemency is in the Oregon Constitution Article V, Section 14; Washington's clemency provision in the Washington Constitution is Article III, Section 9; Colorado's clemency powers are described in Article IV, Section 7 of the Colorado Constitution; Pennsylvania's Constitution gives the governor the power to issue forms of clemency in Article IV, Section 9. These constitutional provisions do not specifically use the word "clemency" to define these powers, though these powers to pardon, grant reprieves, and commute sentences have been understood as powers to clemency.
} 
entitle the defendant to a federal habeas corpus relief and that there are other mechanisms, like the executive's power to grant clemency that can provide this relief. Clemency is a necessity for democracy to protect an individuals and has "provided the 'fail safe' in our criminal justice system.” according to Chief Justice Rehnquist (Herrera v. Collins, 1993). As Chief Justice Rehnquist explained that, "Clemency is deeply rooted in our Anglo-American tradition of law and is the historic remedy for preventing miscarriages of justice when judicial process have been exhausted." (Herrera v. Collins, 1993). Therefore, the powers of clemency act as a check on the justice system and protect individual's liberties and constitutional rights. The understanding is applicable to the states as well, especially since the majority of criminal cases are at the state level.

According Merriam-Webster's law dictionary, a pardon is “a release from legal penalties of an offense" ("Pardon | Definition of Pardon by Merriam-Webster Law Dictionary,” 2018). Pardons are similar to acts of forgiveness. Heads of government use pardons to forgive individuals for crimes they committed. Pardons are the most common ${ }^{8}$ form of clemency issued and have more serious implications than other forms of clemency like commutations and reprieves ${ }^{9}$. In some instances, pardons can be granted even if there has been no criminal proceeding. For example, President Gerald Ford pardoned President Richard Nixon for the Watergate scandal even before there were charges pressed against the President. In the district

\footnotetext{
${ }^{8}$ For example with in the last six presidencies, President Ronald Reagan issued 393 pardons, 13 commutations, and no reprieves; President George H.W. Bush issued 74 pardons, 3 commutations, and no reprieves; President William Clinton issued a total of 396 pardons, 61 commutations, and two reprieves; President George W. Bush granted 189 pardons, 11 commutations, and no reprieves; President Donald Trump has only issued one pardon, one commutation and no reprieves ("Clemency Statistics | PARDON | Department of Justice," 2018). President Barack Obama broke from the tradition of granting more pardons than commutations granting only 212 pardons but a total of 1,715 commutations ("Clemency Statistics | PARDON | Department of Justice," 2018).

${ }^{9}$ Pardons are more serious that reprieves or commutations because the forgive the individual of the total crime whereas commutations and reprieves alter or stall the sentence.
} 
court case, Murphy v. Ford (1975), the Michigan district court determined that President Ford had the constitutional power to grant the pardon even before an indictment or a conviction (Murphy v. Ford, 1975). The district court in Murphy v. Ford (1975) built off of the decision in Ex parte Garland (1866), where it was determined in Justice Field's majority opinion, that the pardoning power is "unlimited" and maybe issued "at any time after its commission, either before legal proceedings are taken, or during the pendency, or after conviction and judgement." (Ex parte Garland, 1866). Justice Field further stated that, "This power of the President is not subject of legislative control...The benign prerogative of mercy reposed in him cannot be fettered by any legislative restrictions." (Ex parte Garland, 1866). The power to issue pardons has been reviewed more than any other clemency power because it is the most expansive and can be often the most controversial.

Commutations, according to the Merriam-Webster Law Dictionary, are "a change of a legal penalty or a lesser one" ("Commutation | Definition of Commutation by Merriam-Webster Law Dictionary," 2018). Commutations can either be on a case by case basis or they can be widespread. For example, Governor Ryan of Illinois commuted the sentence of all death row inmates (163 men and four women) to life imprisonment in 2003 (Wilgoren, 2003). This commutation by Governor Ryan was known as a blanket commutation and was issued in response to the fact that while 12 Illinois death row inmates were executed, 13 death row inmates were exonerated (Chevigny \& Johnson, 2004). Governor Ryan described the Illinois death penalty like flipping a coin, which was viewed as unacceptable for the ultimate punishment (Chevigny \& Johnson, 2004). Commutations, more often than not, are issued on a case by case basis, like other forms of clemency. There are multiple examples in all states and at the federal level of inmate sentences being commuted from one sentence to another. 
A reprieve, on the other hand, is an act "to delay the punishment (of a condemned person)" ("Reprieve | Definition of Reprieve by Merriam-Webster Law Dictionary,” 2018). Reprieves do not forgive individuals for the crimes they committed but instead delay their punishment. Reprieves are similar to pardons and commutations in the sense that they are a form of clemency, but they are different in their application and effect. If someone receives a reprieve, he/she is not forgiven for his/her actions or their sentence converted to a lesser one. Instead, the consequences for their actions are delayed for a certain period of time. Reprieves are also the specific legal vehicle that the current moratoriums in Oregon, Washington, Colorado, and Pennsylvania have been issued.

A moratorium is defined broadly as "an authorized period of delay in the performance of an obligation" or "a suspension of an activity" ("Moratorium | Definition of Moratorium by Merriam-Webster Law Dictionary,” 2018). For example, in 2000 Governor Ryan of Illinois imposed a moratorium on the death penalty before commuting the sentences of all 167 death row inmates (Chevigny \& Johnson, 2004). Governor Glendening of Maryland issued a moratorium in 2002 in order for a study into "whether the death penalty is meted out in a racially discriminatory way.” (Nolan \& Kane, 2015). Governor Bredesen of Tennessee established a moratorium in 2007 for a comprehensive review of the administration of death penalty sentences to be conducted (Nolan \& Kane, 2015).

Though the death penalty is still technically legal in states that currently have moratoriums, no individual death warrant has been, or will be, signed by the governor for execution until either the governor leaves office or changes his/her mind. Prosecutors can still offer the death penalty as a possible sentence when trying individuals. Trials still go through the bifurcated motions established in Gregg v. Georgia (1976). Juries still deliberate the mitigating 
and aggravating factors of the crime and the defendant before determining a sentence of death.

Defendants are still sentenced to death in many states. However, these moratoriums issued by these governors - more precisely reprieves - act as a stay on the actual execution of these individuals. In this application, moratoriums are most similar to a reprieve, though they differ from a reprieve because they delay the sentences for an unknown period and are imposed on multiple inmates for the same reasons. Often, moratoriums are issued for broad reasons that are not specific to the individual case or defendant receiving the reprieve ${ }^{10}$. In Oregon, two individuals have been sentenced to death row since Governor Kitzhaber first announced his moratorium, and one individual has been sentenced to death for a fourth time (Palombo, Glanville, Haberman, \& Hernandez, 2018). Pennsylvanian juries have sentenced two people to death also since Governor Wolf's moratorium was announced ("Pennsylvania Current Execution List," 2018).

Moratorium is a word that is not directly used in the law. Legally, these governors are issuing a broad, universal reprieve for any individual who receives a death penalty conviction. For example, the press release issued by Governor John Kitzhaber on November 22, 2011 did not once use the word "moratorium" though others certainly did ("Gov. John Kitzhaber of Oregon declares a moratorium on all executions | Death Penalty Information Center,” 2011). Similarly, the reprieve announcements by Governor Hickenlooper and Governor Wolf did not mention the word moratorium (Wolf, 2015) (Hickenlooper, 2013). Only the announcement by

\footnotetext{
10 These reasons become crucial in the arguments presented against these moratoriums. Both the Supreme Court of Pennsylvania and Oregon offer some guidance on this issue, though their decision could change depending on if state legislatures enact new statutes or amend their state constitutions, or if the United States Supreme Court rules differently.
} 
Governor Inslee directly describes the Governor's action as a moratorium ${ }^{11}$ (State of Washington Office of the Governor, 2014).

History of Clemency Powers:

The notion of the executive having the power to grant clemency dates back to the ancient governments of Greece and Rome. Julius Caesar used clemency in many different forms, often as a tool for humiliation and "arrogant displays of superiority" throughout his rule (Konstan, 2005). The clemency power as used today by the US government and individual states originates, however, in England under the British monarchy. Pardoning powers in England first appeared in statutes during the reign of King Ine of Wessex (668-725 A.D.) and stated that, "If any one fight in the king's house, let him be liable in all his property, and be it in the King's doom whether he shall or shall not have life" (Duker, 1977). Under King Henry I, the scope of the power to pardon was expanded even further to included more crimes and "so that more abundant pardon [could] be had for those seeking it and more abundant retribution for those transgressing" (Duker, 1977). In 1673, the judicial tribunal in England recognized traditional clemency powers (Duker, 1977). In 1678, Parliament and England faced the question of whether the King, specifically King Charles II, could pardon individuals who were impeached in Parliament (Duker, 1977). It was determined that the King could not issue pardons regarding impeachments, thus limiting the King's clemency power that previously had been determined absolute in 1535. The 1700 Act of Settlement resolved that "no pardon under the great seal of England [shall] be pleadable to an impeachment by the commons in parliament." (Duker, 1977). This statutorily made it so that impeachments were not able to be pardoned.

\footnotetext{
11 This difference will be discussed in further detail later in this analysis.
} 
During America's colonial period, the laws of England applied to the colonies since they were subject to the British Empire. Thus, the prerogative of the pardon was delegated to the governors or executives of the colonies. For example, the Virginia Charter of 1609 granted the governor "full and absolute authority" over pardons (Duker, 1977). The Charter of 1691, which applied to New England, granted a governor appointed by the king to have the power to pardon (Duker, 1977). Different colonies followed suit. Each colony's charter granted the power to pardon to the head of the executive, thus following the established protocol from England (Duker, 1977). Once the colonies broke from England, the common law model from England was utilized by the states both under the Articles of Confederation and the United States Constitution.

During the formation of the Articles of Confederation, considered the first Constitution of the United States, the powers for the federal government to grant clemency were not included. The Articles of Confederation did not include this power, or other powers for the executive branch of government because the Founders feared having a strong executive based on the tyrannical oppression they faced while under British rule. Article II of the Articles of Confederation explicitly stated that, "Each state retains its sovereignty, freedom, and independence, and every power, jurisdiction, and right, which is not by this Confederation expressly delegated to the United States, in Congress assembled" (Articles of Confederation, Article II, 1781). Article III of the Articles of Confederation even describes this union as a "firm league of friendship" (Articles of Confederation, Article III, 1781). Thus, the Articles of Confederation were created to form a union of equally sovereign states, but not a unified nation.

Different state constitutions maintained the power to use clemency within their state, but there was no national power to grant clemency because there was no federal body to issue these forms of clemency nor were there federal crimes that could receive these forms of clemency. The 
citizens were able to decide what pardoning powers would look like as some decided to put legislative limits on the executive's power. For example, Pennsylvania and New York included provisions that, in instances of treason and murder, the governor could grant reprieves until the legislature had time to review the reprieve and determine if a pardon was acceptable (Duker, 1977). Similarly, Article XIX in Georgia's 1777 constitution granted the governor the governor to pardon, through the advice of an appointed council (Duker, 1977). States like Delaware, Virginia, and North Carolina all had similar provisions that granted the executive the power to pardon, except in situations being tried by the legislature (Duker, 1977). New Hampshire restricted the pardoning power to strictly the legislature (Duker, 1977). Massachusetts allowed the executive to only issue pardons after convictions and not for impeachments (Duker, 1977). New Jersey, unlike other states, formed a "court of last resort" which was composed of members of the legislature and governor. The power to issue pardons was bestowed upon the "court of last resort.” (Duker, 1977). State governments, even after the Articles of Confederation, were replaced with the Constitution, still maintained their own versions of executive forms of clemency.

Once it was realized that the Articles of Confederation needed to be changed, the founding fathers met and recreated the United States government. The new US Constitution changed the legislature to a congress composed of two houses and also included the power of the executive and the judiciary. Early proposals like the New Jersey plan and the Virginia plan both did not include the a federal government power to pardon (Duker, 1977). The work of Alexander Hamilton, Charles Pinckney, and John Rutledge, a clause similar to the one established in the 1700 Act of Settlement from England was included (Duker, 1977). The founders did alter the wording of the 1700 Act of Settlement to meet the needs of the United States. Based on the 
proposal from George Mason, the phrase "exception in cases of impeachment" was inserted to replace "but his pardon shall not be pleadable in bar" (Duker, 1977). The establishment of three parts of the federal government, and the checks and balances between them reflected in the idea that the executive's power to pardon could serve as a check to the other branches. The power to pardon was an important component of this because it was able to counteract the any overreach of the judicial system and the laws passed by the legislature. Similarly, the restrictions placed on the executive was a way for the Constitution to counteract the ambition of the executive.

Under Article II Section 2, Clause 1, the "President...shall have the power to grant reprieves and pardons for offenses against the United States, except in cases of impeachment" (US Const. Art. II, § 2). Alexander Hamilton argued that the power to pardon was important in his Federalist Papers to the citizens of New York. In Federalist 69, Hamilton gave an overview of the powers of the executive. He compared the President's power to pardon to that of the executive of New York's power to pardon. "The governor of New York may pardon in all cases...Is not the power of the governor...greater than that of the President?" (Hamilton, 1788b). Hamilton also articulated in Federalist 69 that the fact that presidents cannot grant pardons in instances of impeachment acts as a check on their power, unlike with the governor of New York. In other Federalist Papers, Hamilton expressed the importance of the power to pardon. Specifically, in Federalist 74, Hamilton argued that the power to grant clemency is better placed in the executive than the legislature.

But the principal argument for reposing the power of pardoning in this case to the Chief Magistrate is this: in seasons of insurrection or rebellion, there are often critical moments, when a well-timed offer of pardon to the insurgents or rebels may restore the tranquility of the commonwealth; and which, if suffered to pass unimproved, it may never be possible afterwards to recall. The dilatory process of convening the legislature, or one of its branches, for the purpose of obtaining its sanction to the measure, would frequently be 
the occasion of letting slip the golden opportunity. The loss of a week, a day, an hour, may sometimes be fatal. (Hamilton, 1788a)

Hamilton argued that if the power to grant pardons was vested in the judiciary or the legislature it would take too long to achieve its intended purpose, especially in times when swift action is needed. This delay could be fatal for the nation. Many citizens wanted to avoid the nation failing, especially since the Article of Confederation had just failed so soon after its creation. The power to issue pardons and reprieves was also granted to the executive as a way to establish checks and balances among the three equal branches of government.

Over the centuries, the United States Supreme Court has continued to find that the President's power to grant forms of clemency is somewhat limitless. Chief Justice Taft stated in the majority opinion in Ex parte Grossman (1925) that, "executive clemency exists to afford relief from undue harshness or evident mistakes in the operation or enforcement of the criminal law” (Ex Parte Grossman, 1925). Additionally, Chief Justice Taft, citing Ex Parte Garland (1866) determined that, "The Executive can reprieve or pardon all offenses after their commission, either before trial, during trial or after trial... without modification or regulation of Congress (Ex Parte Grossman, 1925). Likewise, in Ex Parte Garland (1866), the court determined that, "This power of the President is not subject to legislative control. Congress can neither limit the effect of his pardon, nor exclude from it exercise any class of offenders" (Ex Parte Garland, 1866) . Finally, Chief Justice Salmon P. Chase explained in United States v. Klein (1872) that "the executive alone is intrusted [sic] the power of pardon; and it is granted without limit" (United States v. Klein, 1872). Though the clemency powers of the President do not dictate the clemency powers that state constitutions must grant to their respective governors, there are similarities between the president's clemency powers and the clemency powers given to state governors. 


\section{Gubernatorial Clemency Powers:}

Every state in the United States has some form of clemency powers granted to their governors. In Oregon, Washington, Colorado, and Pennsylvania the power to grant clemency is vested in the executive ${ }^{12}$. The governor in Oregon, Washington, and Colorado is the sole individual in charge of clemency based on the powers granted to his/her in their state constitutions. In Pennsylvania, however, the governor is granted the power to issue clemency but the executive must consult with the Board of Pardons to grant a pardon or commute a sentence (Pa. Const. Art. IV § 9). The differences between each state clemency powers are integral in understanding the ability of these governors to issue death penalty moratoriums.

Pennsylvania's Constitution originates during the era of the Articles of Confederation, and thus has a long history compared to Oregon, Washington, and Colorado all of which joined the union many years later. According to the current constitution of Pennsylvania, in Article IV Section 9, the power to pardon or grant clemency is vested in both the executive and the Board of Pardons.

(a)In all criminal cases except impeachment the Governor shall have power to remit fines and forfeitures, to grant reprieves, commutation of sentences and pardons; but no pardon shall be granted, nor sentence commuted, except on the recommendation in writing of a majority of the Board of Pardons, and, in the case of a sentence of death or life imprisonment, on the unanimous recommendation in writing of the Board of Pardons, after full hearing in open session, upon due public notice. The recommendation, with the reasons therefor at length, shall be delivered to the Governor and a copy thereof shall be kept on file in the office of the Lieutenant Governor in a docket kept for that purpose. (Pa. Const. Art. IV §9)

\footnotetext{
12 This power is sometimes limited in cases of impeachment or treason (Or. Const. Art. V, §14) (Co. Const. Art. IV, $\S 7$ ) though it is generally broad and unrestricted like the President's power to grant clemency.
} 
The Pennsylvania Constitution, also in Article IV Section 9 declares that the composition of the Board of Pardons:

... of the Lieutenant Governor who shall be chairman, the Attorney General and three members appointed by the Governor with the consent of the majority of members elected to the Senate for terms of six years. The three members appointed by the Governor shall be residents of Pennsylvania. One shall be a crime victim, one a corrections expert and the third a doctor of medicine, psychiatrist or psychologist. The board shall keep records of its actions, which shall at all times be open for public inspection. (Pa. Const. Art. IV $\S 9)$

The Board of Pardons established in the Pennsylvania Constitution is unique to Pennsylvania for this analysis. The state constitutions of Oregon, Washington, and Colorado do not require a Board of Pardons or other advisory boards similar in nature for its governors to grant clemency. Historically, this was not always the case for Pennsylvania. The 1681 Charter of Pennsylvania, signed by King Charles II, granted William Penn the power to pardon all crimes and offenses "except treason and murder" (Pennsylvania Board of Pardons, 2018). Pennsylvania state constitutions from 1790 and 1838 also provided the state governor with exclusive and "unfettered" power to issue clemency (Pennsylvania Board of Pardons, 2018). This changed, however, at the Constitutional Convention in 1872; due to allegations of executive abuse, the Board of Pardons (Article IV § 9) was established (Pennsylvania Board of Pardons, 2018). The Board of Pardons has been part of the Pennsylvania Constitution since 1872 and the portion of Article IV section 9 that describes the Board of Pardons has only been amended once. In 1997, a clause was added requiring a unanimous vote to recommend a commutation of a life or death sentence (Pennsylvania Board of Pardons, 2018). The Board of Pardons distinguishes the Governor's clemency powers in Pennsylvania from Oregon, Colorado, and Washington Governors' clemency powers. 
Oregon joined the union as a state on February 14, 1859. The Oregon Constitution was influenced significantly by other state constitutions. Delegate Paul Brattain had been a delegate at the Iowa Constitutional Convention in 1844 (Burton, 2003). Matthew Deady, president of the Oregon Constitutional Convention, referenced the proceedings of the New York Constitutional Conventions of 1826 and 1841, and delegate La Fayette Grover had a collection of recently published state constitutions that he referenced during the convention (Burton, 2003). Therefore, the influence of other state constitutions was central to the creation of the Oregon Constitution. Article V, Section 14, describes the clemency powers of the executive in Oregon as:

He shall have power to grant reprieves, commutations, and pardons, after conviction, for all offenses [sic] except treason, subject to such regulations as may be provided by law. Upon conviction for treason he shall have power to suspend the execution of the sentence until the case shall be reported to the Legislative Assembly, at its next meeting, when the Legislative Assembly shall either grant a pardon, commute the sentence, direct the execution of the sentence, or grant farther [sic] reprieve. -

He shall have power to remit fines, and forfeitures, under such regulations as may be prescribed by law; and shall report to the Legislative Assembly at its next meeting each case of reprieve, commutation, or pardon granted, and the reasons for granting the same; and also the names of all person in whose favor remission of fines, and forfeitures shall have been made, and the several amounts remitted [.] (Or. Const. Art. V § 14).

The Oregon Constitution, unlike the Pennsylvania Constitution, grants broader clemency power to the executive, though the governor is limited in utilizing absolute clemency in instances of treason. The legislature in Oregon is also allowed to pass laws that limit the governors power to grant clemency. Article V section 14 states that the governors clemency power is, "subject to such regulations as may be provided by law." (Or. Const. Art. V §14).

Colorado joined the union a little less than twenty years after Oregon on August 1, 1876. In Article IV, Section 7, the Colorado Constitution grants the governor the power to issue reprieves and pardons: 
The governor shall have power to grant reprieves, commutations and pardons after conviction, for all offenses except treasons, and except in case of impeachment, subject to such regulations as may be prescribed by law relative to the manner of applying for pardons, but he shall in every case where he may exercise this power, send to the general assembly at its first session thereafter, a transcript of the petition, all proceedings, and the reasons for his action. (Col. Const. Art IV § 7).

The Colorado Constitution grants similar clemency power to the executive like Oregon's

Constitution does. This similarity will be important later on in this analysis. Similar to the Oregon Constitution, the Colorado Constitution also allows for the legislature to limit the governor's clemency power through laws.

Washington became a state on November 11, 1889. Article III $\S 9$ of the Washington Constitution grants the executive the power to issue pardons. "The pardoning power shall be vested in the governor under such regulations and restrictions as may be prescribed by law" (Wa. Const. Art III § 9). The Washington Constitution's issuance of clemency powers is very similar to the powers granted in both Oregon and Colorado, although there are some key differences. The Washington Constitution provision for governor clemency power is simpler and shorter than both Oregon and Colorado's constitutions, but it also has more ambiguities than the other two. The Washington Constitution offers the potential for the Governor's clemency powers to be even broader and even more limitless than Oregon or Colorado's clemency powers.

\section{History of the Death Penalty:}

The death penalty is not unique to the United States. The death penalty was a common form of punishment under the ancient laws of China, the $18^{\text {th }}$ century codes of Babylon, and in ancient governments like ancient Greece and Rome (Reggle, 1997). Internationally, views regarding the death penalty have changed and the United States is now one of a minority of nations that allow the death penalty. For example, in 1977, sixteen countries across the world had 
abolished the death penalty; by 2015, 140 countries had abolished the death penalty (Radelet, 2017). Fifty-eight countries still practice the death penalty and the most executions occur in China, Iran, Iraq, Saudi Arabia and the United States (Radelet, 2017). The only industrialized democracy similar to the United States that retains capital punishment is Japan (Radelet, 2017).

The death penalty and its constitutionality throughout history have been questioned based on the Eighth Amendment. The Eighth Amendment requires that "Excessive bail shall not be required, nor excessive fines imposed, nor cruel and unusual punishments be inflicted" (US Const. amend VIII). The Eighth Amendment was influenced by the Magna Carta of 1215, the 1682 Frame of Government of Pennsylvania, the English Bill of Rights of 1689, and the Virginia Declaration of Rights of 1776 (Bessler, 2012). The Eighth Amendment was intended to protect individuals from the horrific forms of punishment that were used in England (Bessler, 2012).

As society has evolved, the definition of "cruel and unusual" as evolved as well. Several Supreme Court Justices in different cases have used "evolving standards of decency" to determine what is "cruel and unusual." The United States Supreme Court first recognized in 1910 that societal standards change as society changes (Weems v. United States, 1910). The phrase "evolving standards of decency" was first used in Trop v. Dulles (1958), where the court argued "The [Eighth] Amendment must draw its meaning from the evolving standards of decency that mark the progress of a maturing society" (Trop v. Dulles, 1958). The notion of evolving standards of decency have been used by Justices to determine if current criminal practices, especially regarding the death penalty, violate the Eighth Amendment. The Supreme Court in 1977 determined that the death penalty could not be applicable for crimes of rape (Coker v. Georgia, 1997) and in 2008 determined that the death penalty was a cruel and unusual punishment for crimes of juvenile rape (Kennedy v. Louisiana, 2008). Similarly, in 2002, the 
Supreme Court decided that it was cruel and unusual to execute individuals with serious mental illnesses and mental impairments (Atkins v. Virginia, 2002). In 2005, the Supreme Court decided that it was unconstitutional to execute individuals of aggravated murder if they are under the age of eighteen (Roper v. Simmons, 2005). The evolution of Supreme Court opinions on who may be sentenced to death, for what reasons, and for what crimes have largely been determined by this standard.

State History of the Death Penalty:

The death penalty was frequently used as a form of punishment throughout European history and thus directly influenced the colonist of the United States views on punishment for crimes. In the 1700s in Great Britain, there were 222 crimes that were punishable by death (Reggle, 1997). In the United States, the death penalty dates back to as early as 1608 , when the colonists "transplanted" English common law to the colonies (Buenviaje, 2010). To the colonists, and in the majority of the United States formative years, the death penalty was seen "as the only way to deter serious crime, such as murder" (Buenviaje, 2010). This analysis will focus primarily on the history of the death penalty in Pennsylvania, Oregon, Colorado, and Washington to explain how this history has influenced the current moratorium.

\section{Pennsylvania:}

Pennsylvania citizens, like other citizens of the original colonies, followed the lead of England when the death penalty penal code was established, though the colonists never resorted to the extremes of the English capital punishment code (Post, 1944). At the early stages of the history of the colony of Pennsylvania, only willful murder was punishable by death ${ }^{13}$. In 1718

\footnotetext{
${ }^{13}$ There were more crimes that were punishable by death if you were a slave during this time period. For example, after 1700, slaves were punished with the death penalty for murder, rape, buggery, and burglary (Post, 1944).
} 
due to the compromise over the right of affirmation, the English criminal code was introduced in the colony's criminal code; more crimes were punishable by death than originally intended by the settlers of Pennsylvania (Post, 1944). The crimes of manslaughter, rape, highway robbery, maiming, burglary, arson, witchcraft, sodomy, and eventually counterfeiting, squatting on Indian land, and prison-breaking were added to the law to be crimes punishable by death (Buenviaje, 2010). Despite these additional crimes that were now punishable by death, capital punishment was used haphazardly in Pennsylvania, with the first execution under this law taking place eighteen years later for the crime of burglary (Buenviaje, 2010).

No changes were made to the Pennsylvania criminal code regarding the death penalty until 1786, when the numbers of crimes were "greatly reduced" (Post, 1944). During this time period, different reform and abolitionist groups formed to persuade the legislature against capital punishment. One of the earliest opponents of the death penalty, Attorney General William Bradford, was the "moving force" behind the 1794 Pennsylvania statute which punished only murder in the first degree with death. This was the first statute in the United States that distinguished between first degree murder and second degree murder (Post, 1944). In Pennsylvania, according to the statute, "murder...perpetrated by means of poison, or by lying wait, or by any other kind of willful, deliberate, or premeditated killing, or which shall be committed in the perpetration, or attempt to perpetrate, any arson, rape, robbery or burglary..." was punishable by death (Post, 1944). Further, by the end of the nineteenth century, executions were no longer in public places or available to the public (Buenviaje, 2010). In 1824, the Pennsylvania legislature heard the first bill on banning public executions (Buenviaje, 2010). This specific bill did not pass the legislature; however, a similar bill was eventually passed and public executions were banned. 
There were many abolition movements in the early history of the state of Pennsylvania ${ }^{14}$, nevertheless, none of them succeeded. For example, the legislature of Pennsylvania started receiving petitions to abolition the death penalty in 1809 , but neither the House nor the Senate of Pennsylvania could ever reach a majority opinion to abolish the death penalty (Post, 1944). Frequently, decisions by the legislature about abolishing the death penalty were postponed until future sessions. During the legislative session of 1812, on March 5 the Senate adopted a resolution to bring forth the bill for abolition, but consideration was postponed on March 11 to be considered during the next legislative session (Post, 1944). Again, in 1831, both the Senate and the House of Pennsylvania voted to postpone consideration for a resolution to abolish capital punishment, with a similar resolution of this nature being postponed in 1836 (Post, 1944). Pennsylvania had never abolished the death penalty up until the United States Supreme Court decision in Furman v. Georgia (1972).

The Pennsylvania Supreme Court found in Commonwealth v. Bradley (1972) that the state of Pennsylvania's death penalty procedures violated the federal constitution based on the United States Supreme Court decision of Furman v. Georgia (1972) ("Pennsylvania | Death Penalty Information Center," 2018). As a result of this decision, the death row in Pennsylvania was emptied and the sentences of these inmates were judicially commuted to life imprisonment (“Pennsylvania | Death Penalty Information Center," 2018). This decision did not sit well with the citizens of Pennsylvania or their legislature. In the 1974 legislative session, the Pennsylvania legislature passed a new bill that would reinstate the death penalty according to the guidelines

\footnotetext{
${ }^{14}$ Pennsylvania technically is a commonwealth and is one of the four commonwealths in the United States. The four commonwealths in the United States are Pennsylvania, Kentucky, Virginia, and Massachusetts. A commonwealth is a body of people organized under a single government. These four are not officially referred to as a state but there is no real significant difference between these four commonwealths and the rest of the States of the United States (Emelda, 2017).
} 
established by the United States Supreme Court in Furman v. Georgia (1972) ("Pennsylvania | Death Penalty Information Center,” 2018). Governor Milton Shapp vetoed the bill, but the legislature overrode this veto and the bill became law ("Pennsylvania | Death Penalty Information Center," 2018). The new death penalty law was found unconstitutional by the state supreme court, however, in 1977 which resulted in the law being revised and passed in 1978, again over the veto of Governor Shapp ("Pennsylvania | Death Penalty Information Center," 2018).

More recently, in 2011, the Pennsylvania legislature passed Senate Resolution 6 (Wolf, 2015). The result of this resolution was the establishment of the Pennsylvania Task Force and Advisory Committee on Capital Punishment ${ }^{15}$ (Wolf, 2015). The resolution was introduced on January 12, 2011 and amended on December 6, 2011 (Greenleaf et al., 2011). The Senate, as described in the resolution, argued that a task force to review capital punishment in Pennsylvania was necessary for a multitude of reasons. First, "Three hundred and fifty two people have been sentenced to death in Pennsylvania but only three people have been executed," but those three people that were executed waived their right to appeal (Greenleaf et al., 2011). Second, questions continued to be asked "regarding the costs, deterrent effect and appropriateness of capital punishment.”(Greenleaf et al., 2011). Third, the American Bar Associate had also identified several failures of the Pennsylvania death penalty (Greenleaf et al., 2011). Fourth, the Pennsylvania Supreme Court Committee on Racial and Gender Bias in the Justice System determined there were biases based on race, ethnicity, and gender in the Pennsylvania capital punishment system and Pennsylvania University, at the time, was currently conducting research

\footnotetext{
15 The Pennsylvania Task Force and Advisory Committee on Capital Punishment will be referred to as the task force in this paper.
} 
on the same issue (Greenleaf et al., 2011). Fifth, post-conviction DNA testing had proven wrongful convictions (Greenleaf et al., 2011). As a result, the senate resolution called for the establishment of a bipartisan task force of four members of the senate and an advisory committee of approximately thirty members who were representative of "groups most likely to make useful and insightful contributions ${ }^{16 "}$ (Greenleaf et al., 2011). Senate Resolution 6 proposed that the task force and the advisory committee would study many different subjects related to the death penalty in Pennsylvania such as: cost, bias and unfairness, proportionality, the impact on and services for family members, "mental retardation"17, mental illness, juries, state appeals and post-conviction, clemency, penological intent, innocence, alternatives, counsel, secondary trauma, length and conditions of confinement on death row, lethal injection, and finally public opinion (Greenleaf et al., 2011). The resolution called for the committee to report its findings "no later than two years after the date this resolution is adopted" (Greenleaf et al., 2011) ${ }^{18}$. Senate Resolution Number 6 is integral to understand the reason behind Governor Tom Wolf's issuance of the Pennsylvania Death Penalty moratorium and why the moratorium is still in place.

On February 13, 2015, Governor Tom Wolf of Pennsylvania released a memorandum to explain why he was granting a reprieve to inmate Terrance Williams. Governor Wolf stated, "The reprieve announced today shall remain in effect until I have received and reviewed the forthcoming report of the Pennsylvania Task Force and Advisory Committee on Capital

\footnotetext{
${ }^{16}$ The resolution describes these individuals as members of the judiciary, prosecution, defense, law enforcement, corrections, victim assistance organizations and representatives of academia, the religious community, private and public organizations involved in criminal justice, and other criminal justice experts (Greenleaf et al., 2011).

${ }^{17}$ The resolution distinguishes individuals with a mental illness and individuals with low mental IQ from each other. The resolution uses the word "mental retardation" to describe these individuals with a low IQ though the DSM-5 and the federal government - under Rosas Law - now recognize the term "intellectually disabled" as the proper way to describe these individuals (Diament, 2010).

${ }^{18}$ The Task Force has still not issued a report on this matter to the Governor, as will be discussed later in this analysis.
} 
Punishment, and any recommendations contained therein are satisfactorily addressed. In addition, it is my intention to grant a reprieve in each future instance in which an execution is scheduled until this condition is met" (Wolf, 2015). Governor Wolf explained that he issued this temporary reprieve and all future reprieves because, "In the nearly forty years since the Pennsylvania General Assembly reinstated the death penalty, the Commonwealth has executed three people, all of whom voluntarily abandoned their right to further due process" (Wolf, 2015). Governor Wolf argued that, "the only certainty in the current system is that the process will be drawn out, expensive, and painful for all involved" (Wolf, 2015). Previously, as Governor Wolf pointed out, the Task Force in September, 2012 called for then Governor Corbett to suspend executions until the group had conducted its research but Governor Corbett did not suspend executions (Wolf, 2015). As a result, Governor Wolf issued the temporary reprieve of Terrance Williams until Governor Wolf is able to carefully review the report and recommendations of the Task Force and Advisory Committee on Capital Punishment and has the opportunity to address any of the concerns the report may raise (Wolf, 2015).

\section{Oregon:}

Throughout the state of Oregon's history, there have been many debates, initiatives, and referendums to either repeal or reinstate the death penalty. The controversial nature of the death penalty has been at the forefront of Oregon politics since the state was a territory. Measures related to the death penalty have been on the ballot seven times, which is more than in the history of any other state (Long, 2001). The territorial legislature in 1850 "dramatically changed the murder statute and capital punishment in Oregon, adopting a 'Pennsylvania-style' statute by breaking murder into two degrees and by including a felony murder component." (Long, 2001). It is important to note that even though this adoption of a "Pennsylvania-style" murder and 
capital punishment statute took place under the territorial legislature; these changes influenced the laws that were later implemented by the state legislature. The first criminal code, enacted after statehood, was the Deady Code of 1864 which authorized the death penalty for first degree murder and treason (Long, 2001). The Deady Code of 1864 also called for executions to be conducted by each individual county instead of by the state. This portion of the law only lasted for 44 years because it was unpopular with citizens as it resulted in public executions (Long, 2001). In 1874, the state legislature passed a statute that required executions to "take place 'within the enclosure of the jail or jail yard where the defendant is confined, and in the presence of twelve bona fide electors of the county to be selected by the Sheriff of said county."' (Long, 2001). Even though the law shifted executions to a private forum, the public still attended; citizens would buy tickets, bribe guards, and form huge crowds to see someone executed.

The state of Oregon and its citizens faced their first abolition movement during 1911 1920 (Long, 2001). Under the leadership of Governor Oswald West, Oregonians fought for and voted on the abolition of the death penalty in 1912 and 1914 (Long, 2001). The abolition movement first failed in 1912 . The abolition movement brought the issue back in $1914^{19}$ in the form of an initiative petition to successfully amend the Oregon Constitution (Long, 2001). Article I Section 36 was added to the Oregon Constitution, which stated, "The death penalty shall not be inflicted upon any person under the laws of Oregon. The maximum punishment which may be inflicted shall be life imprisonment." (Long, 2001). The constitutional initiative, however, barely passed in 1914 by a vote of $50.04 \%$ to $49.96 \%$ (Long, 2001). This constitutional

\footnotetext{
${ }^{19}$ In 1914, women were now allowed to vote in the state of Oregon. The larger number of voters potentially contributed to this abolition movements success (Long, 2001).
} 
amendment only last a few years, and was repealed in 1920 during a special election, Oregon citizens had voted to restore the death penalty (Long, 2001).

The citizens of Oregon experienced their second abolition movement in 1957-1964. During the 1958 election, abolitionists sought to abolish the death penalty through a constitutional amendment by means of a legislative referral but this effort failed by 12,000 votes (Long, 2001). A similar repeal effort was again brought forward in 1964 and this time succeeded by 153,000 votes (Long, 2001). The 1964 repeal effort offered broader, less prescriptive verbiage for repealing the death penalty. Known as Senate Joint Resolution 3, the repeal stated, "Sections 37 and 38, Article 1 of the Constitution of the State of Oregon, are repealed.” (Long, 2001). After the repeal effort had been passed by the voters, Governor Mark Hatfield commuted the sentences of all of those on death row to life in prison (Long, 2001).

The national confusion caused by the Furman v. Georgia decision did not have huge implications in the state of Oregon, however, because there was no death penalty statute at this time. Nevertheless, the issue of the death penalty was not gone from the minds of Oregon citizens or the legislature. The murder of a Eugene couple in 1974 by Carl Cletus Bowles, who had used a social pass to escape the Oregon State Penitentiary, led to many citizens call for the death penalty to be reinstated (Long, 2001). A statutory initiative petition to reinstate the death penalty was on the ballot and was approved by the voters in November 1978. The death penalty was deemed unconstitutional by the Oregon Supreme Court in 1981, but voters, insistent that there be a death penalty in Oregon, reinstated the death penalty again in 1984 ("Oregon | Death Penalty Information Center,” 2018). The death penalty in Oregon has been reinstated since 1984, but has only been used to execute two individuals, Douglas Franklin Wright in 1996 and Harry 
Charles Moore in 1997, both of whom chose to waive the appeals process (Oregon Department of Corrections, 2000) $)^{20}$.

The death penalty moratorium in Oregon was first started by Governor Kitzhaber in 2011 and has been carried on by current governor, Governor Kate Brown. On Friday November 18, 2011, Oregon death row inmate Gary Haugen waved his right to appeal and volunteered to die. A death warrant was issued for Haugen on that day. On Monday November 22, 2011 Governor John Kitzhaber issued a press release declaring that he would "issue a temporary reprieve in the case of Gary Haugen for the duration of my term in office" ("Gov. John Kitzhaber of Oregon declares a moratorium on all executions | Death Penalty Information Center,” 2011). Though Governor Kitzhaber did not use the word moratorium to describe his actions, this "temporary reprieve" started the current moratorium in Oregon.

In this press release, Governor Kitzhaber explained that he was issuing this "temporary reprieve" for many reasons. First, Governor Kitzhaber stated that he is morally opposed to the death penalty and cannot participate in authorizing individuals to be executed again when it goes against his moral convictions, "I do not believe that those executions made us safer; and certainly, they did not make us nobler as a society. And I can simply cannot participate once again in something I believe to be morally wrong." ("Gov. John Kitzhaber of Oregon declares a moratorium on all executions | Death Penalty Information Center,” 2011). Second, Governor Kitzhaber argued that:

"The death penalty as practice in Oregon is neither fair nor just; and it is not swift or certain. It is not applied equally to all. It is a perversion of justice that the single best

\footnotetext{
${ }^{20}$ Governor John Kitzhaber signed both of these inmates' death warrants during his first tenure as Governor. Governor Kitzhaber's participation in these executions greatly influenced why he decided to issue a temporary reprieve for the duration of his term for inmate Gary Haugen, as he explained in his November 22, 2011 press release.
} 
indicator of who will and will not be executed has nothing to do with the circumstances of a crime or the findings of a jury. The only factor that determines whether someone will be sentenced to death in Oregon is actually executed is that they volunteer. The hard truth is that in the 27 years since Oregonians reinstated the death penalty, it has only been carried out on two volunteers who waived their right to appeal." ("Gov. John Kitzhaber of Oregon declares a moratorium on all executions | Death Penalty Information Center," 2011)

The moratorium that Governor Kitzhaber started in 2011 has continued today though there is a different governor in power. Governor Kate Brown, as announced through her spokesman, Bryan Hockaday, that she would be continuing on the death penalty moratorium “...because after thoroughly researching the issue, serious concerns remain about the constitutionality and workability of Oregon capital punishment law.” (Hernandez, 2016). Hockaday also said that Governor Brown was continuing the moratorium because of the "uncertainty of Oregon's ability to acquire the necessary execution drugs required by statute" citing the issues faced nationally with requiring the lethal injection drugs (Hernandez, 2016). There have been no changes to the death penalty moratorium in Oregon under Governor Brown's tenure.

\section{Washington:}

Washington State's death penalty history is similar to the death penalty history of Oregon because of the common territorial history between the two states. In 1853, Washington became an official territory with Isaac Stevens appointed as the first governor of the territory (Laythe, 2010). AAs the population grew in both the territory of Washington, tensions between white settlers and Native American tribes caused conflicts and tension. Between 1850 and 1889, Native Americans were more likely to face the death penalty than white settlers in the area; 46 percent of the executions that occurred in the Washington Territory were of Native Americans (Laythe, 2010). 
Washington was granted statehood in 1889 and experienced a large population boom between the formation of statehood and the end of World War I (Laythe, 2010). This population boom also signified a changing of societal views. The death penalty was abolished in 1913 by the voters in Washington as an initiative ("Washington | Death Penalty Information Center," 2018). This abolition was short-lived as the murder of a prominent business leader in Washington in 1917 sparked a call for a restoration of the death penalty (Laythe, 2010). Joseph Laythe, historian of the death penalty in the Pacific Northwest, has also argued that the labor strikes occurring in Seattle, the threat of bolshevism that was felt across the country, and the increase in crime, resulted in the reinstatement of the Washington death penalty on March 14, 1919 (Laythe, 2010). Between 1920 and 1963, fifty-eight individuals were executed in Washington (Laythe, 2010).

The death penalty in the state of Washington had, since the 1960's, experienced a tumultuous road. As a response to the United States Supreme Court's decision in Furman v. Georgia (1972), Washington's legislature again abolished capital punishment in 1975 (Laythe, 2010). This abolition was very brief, as citizens on November 4,1975 voted through a state referendum to reestablish the death penalty (Laythe, 2010). However, the death penalty was not fully reinstated in the state until 1977 in order to follow the United States Supreme Court decision (Laythe, 2010). When capital punishment was reintroduced, the death penalty was instituted as the mandatory sentence for first-degree aggravated murder (Laythe, 2010). Shortly after the death penalty was reinstated by the Washington citizens, the Washington Supreme Court struck down the initiative in the case State v. Green "on the grounds that it violated the cruel and unusual punishment provisions of the Bill of Rights." (Laythe, 2010). Then the death penalty was reinstated again by law in 1981 ("Washington | Death Penalty Information Center," 
2018). The last man to be executed in the state was Charles Rodman Campbell; he was executed on May 27, 1994 by hanging ${ }^{21}$ (Laythe, 2010).

Governor Jay Inslee, on February 11, 2014 announced that he, "[Had] decided to impose a moratorium on executions while I'm Governor of the State of Washington." (State of Washington Office of the Governor, 2014). Governor Inslee articulated that he was imposing this moratorium ${ }^{22}$ because, "The use of the death penalty in this state is unequally applied" (State of Washington Office of the Governor, 2014). Governor Inslee argued five reasons why he was placing a moratorium on the death penalty. First, there is a lack of individuals that are actually executed in the state. "Since 1981...32 defendants have been sentenced to die. Of those, 19, or $60 \%$, had their sentences overturned... When the majority of death penalty sentences lead to reversal, the entire system itself must be called into question" (State of Washington Office of the Governor, 2014). Second, Governor Inslee argued that the costs associated with capital punishment "outweigh the price of locking someone up for life without the possibility of parole." (State of Washington Office of the Governor, 2014) Third, Governor Inslee addressed his concerns with how "death sentences are neither swift nor certain" and that, "While [the inmates] sit on death row and pursue appeal after appeal, the families of their victims must constantly revisit their grief at the additional court proceedings" (State of Washington Office of the Governor, 2014). Fourth, citing a study done by the National Academy of Science, Governor Inslee stated that there is no "credible evidence that the death penalty is a deterrent to murder."

\footnotetext{
${ }^{21}$ Washington is the only state that still has the gallows as a method of execution. Lethal injection is the default method for execution, though inmates are allowed to choose the gallows if that is their preferred method. ("Washington | Death Penalty Information Center," 2018).

${ }^{22}$ Governor Kitzhaber, Governor Wolf, and Governor Hickenlooper all described their action as a reprieve, whereas Governor Inslee is the only governor to describe his actions as a moratorium. This most likely is because the other governors initiated their moratoriums by granting a broad reprieve to a specific inmate, where as Governor Inslee announced the moratorium before granting a reprieve to anyone (State of Washington Office of the Governor, 2014).
} 
(State of Washington Office of the Governor, 2014). Finally, according to Governor Inslee, the death penalty is not always applied to the most heinous offenders (State of Washington Office of the Governor, 2014). Recently, as a response Governor Inslee's moratorium, the Washington State Senate passed a bill by a 26 to 22 vote to abolish the death penalty in February, 2018 (Wasserman, 2018). The bill must still be reviewed by the Washington State House of Representatives before Governor Inslee can sign it into law.

\section{Colorado:}

The State of Colorado has dealt with issues about the death penalty from the beginning of its states history. Congress passed a bill in 1861 to create the Colorado Territory and Governor William Gilpin on November 5, 1861 signed into law the first statute that authorized the death penalty in the territory of Colorado (Radelet, 2017). Once Colorado was granted statehood in 1877, the legislature adopted the pre-existing 1868 death penalty statute with the 1870 's amendment to be the official death penalty statute for the new state of Colorado (Radelet, 2017). The 1870 amendment to the 1868 death penalty statute stated:

"The legislation...limited to availability of the death penalty to cases in which the jury found not only that the defendant was guilty of murder, but also that the killing was deliberate, premeditated, or committed during the perpetration (or attempted perpetration) of a felony" (Radelet, 2017)

The 1870 amendment created a loophole in which defendants who plead guilty and avoided a jury trial were able to avoid being sentenced to death.

Coloradans and their legislature experienced its first abolitionist movement in the late $19^{\text {th }}$ century. In 1893 and 1895 , the state Senate passed two different bills to abolish the death penalty, but both of them were defeated in the state House of Representatives (Radelet, 2017). In 
1897, however, House Bill 74, "which proposed to abolish the death penalty and substitute for it a punishment of life imprisonment" passed both the House of Representatives and the Senate and was signed into law on March 29, 1897 by Governor Alva Adams (Radelet, 2017). The abolition in Colorado was brief, however, as different murders occurred that caused the citizens of Colorado to resort to forms of vigilante justice. For example, sixteen-year-old John Preston Porter Jr. was burned at the stake in front of a crowd of seven hundred for the alleged murder of the eleven to thirteen year old ${ }^{23}$ Louise Frost (Radelet, 2017). The lynching of John Preston Porter Jr. was not the first of its kind during this time period, but it was the final straw that resulted in the state legislature reevaluating the death penalties place in Colorado.

The Colorado House of Representatives voted to reinstate the death penalty in Colorado on February 8, 1901 by a 41-24 vote; this bill was then passed in the Colorado Senate on March 29, 1901 (Radelet, 2017). Surprisingly, this bill became law without the signature of the governor. Governor James B. Orman refused to either sign the bill or veto it and as a result, the bill became effective without an executive signature on July 31, 1901 (Radelet, 2017). Under this new law, "sixty-five people were put to death between 1905 and 1967, with just over half (thirtythree) sent to the hereafter with a noose" and the rest being executed in by asphyxiation in a gas chamber (Radelet, 2017). The gas chamber was adopted in Colorado in 1933 and replicated the gas chamber used in Nevada largely because it was the most modern method and was seen as being the most civilized way to execute criminals (Radelet, 2017). Executions by gas took place from 1933 to 1967 in the state of Colorado (Radelet, 2017). Luis José Monge was executed on June 2, 1967 (Radelet, 2017). He was the last man to be executed in Colorado and he was the last

\footnotetext{
${ }^{23}$ There is some uncertainty over the exact age of Louise Frost, but it has been suggested that she was somewhere between the age of eleven and thirteen (Radelet, 2017).
} 
man to be executed in the United States before the United States Supreme Court invalidated the death penalty through the Furman v. Georgia (1972) decision (Radelet, 2017).

As a response to the Furman v. Georgia (1972) decision, the legislature of Colorado in 1974 passed a new capital punishment statute that, hopefully, fell in line with the requirements of the Furman decision (Radelet, 2017). The Colorado statute was upheld in 1976 with the United States Supreme Court's ruling of Gregg v. Georgia (1978). The Colorado Supreme Court, however, in 1978 ruled that the death penalty statute, "was unconstitutional because it failed to allow juries to consider the full range of mitigating factors related to the circumstances of the offense or the offender in their sentencing decisions" (Radelet, 2017). The statute was revised and "required juries to decide (1) if at least one statutorily specified aggravated factor existed, (2) if any mitigating factors existed, (3) whether or not the mitigating factors outweighed aggravating factors, and (4) if the defendant should be sentenced to death or life in prison." (Radelet, 2017). In 1988, the Colorado legislature again changed the death penalty statute to call for lethal injection as the method for execution instead of lethal gas (Radelet, 2017). In 1991, the Colorado legislature, in response to the Colorado Supreme Court, amended the death penalty statute to include the possible sentence of life without the possibility of parole (LWOP) (Radelet, 2017). In 1995, Colorado's legislature then decided to remove the life or death decision from jurors to a three-judge panel, though this change to the legislation only lasted until 2002, when the United States Supreme Court ruled in Ring v. Arizona (2002) that life or death decisions must be made by a jury (Radelet, 2017).

Governor John Hickenlooper, the current governor of Colorado, established the capital punishment moratorium there on May 22, 2013 (Augé et al., 2013). Governor Hickenlooper, 
issued a temporary reprieve for death row inmate Nathan Dunlap ${ }^{24}$, instead of issuing other forms of clemency such as a pardon or a commutation. The temporary reprieve issued by Governor Hickenlooper meant that Dunlap would not be executed until either the Governor changed his mind or the Governor left office (Radelet, 2017). Governor Hickenlooper argued that, "Colorado's system of capital punishment is imperfect and inherently inequitable" and that, "Such a level of punishment really does demand perfection." (Augé et al., 2013). Hickenlooper elaborated that though the reprieve is "temporary" it would be highly unlikely he would sign a warrant authorizing execution (Augé et al., 2013). Governor Hickenlooper explained that, "It is a legitimate question whether we as a state should be taking lives...Because the question is about the use of the death penalty itself, and not about Offender No. 89148, I have opted to grant a reprieve and not clemency in this case." (Augé et al., 2013). Governor Hickenlooper also argued that an execution would not readily take place in the State of Colorado due to the issues regarding getting the drugs used for lethal injection (Augé et al., 2013). Governor Hickenlooper has maintained the death penalty moratorium in Colorado into his second term as governor and there have been efforts in the state Senate to repeal the death penalty (Eason \& Frank, 2017).

\section{Current Moratoriums:}

Governors are not allowed to enact laws or rules at the drop of a hat or by magic. Instead, explicit and implicit powers are granted to these individuals through state constitutions. These constitutions are instituted by the people of the state, thus the power granted to the Governor is derived from the people and is a reflection of the views of the people. While state executives are entrusted with a wide range of powers, the power to grant clemency have gone unchecked.

\footnotetext{
${ }^{24}$ Governor Hickenlooper only refers to inmate Dunlap by name a couple times in his memorandum. Instead, he often refers to Dunlap as Offender No. 89148.
} 
Historically, whether it be the United States Supreme Court or state supreme courts, it has been determined that this power is "granted without limit" (United States v. Klein, 1872). Governors John Kitzhaber, John Hickenlooper, Jay Inslee, Tom Wolf, and Kate Brown have used the broad interpretation of their clemency powers to issue expansive and somewhat indefinite reprieves to death row inmates. These reprieves were not necessarily requested by the individual and were not conducted on a case by case basis. Instead, these governors utilized their unlimited clemency powers to issue a one-size-fits-all reprieve for death row inmates in their respective state. There is little case law on this topic. The supreme courts of Oregon and Pennsylvania have heard and issued opinions on whether their governors can use their power this sweepingly, but there has been no federal or United States Supreme Court opinion on this matter. This section will focus on the current case law on this topic, the state constitutions, the United States constitution, and the history of clemency powers in the United States to argue that because of the lack of restrictions, governors are able to use their power this broadly.

\section{Summary of the Washington and Colorado Moratorium:}

The Supreme Court of the State of Washington has not heard a case nor has it ruled on the constitutionality of Governor Jay Inslee's sweeping moratorium. It can be assumed that because of the broad definition of pardoning powers provided in the Washington Constitution, the Washington Supreme Court would likely find that Governor Inslee was acting within his powers as governor based on the example from the Oregon Supreme Court and the Pennsylvania Supreme Court. The moratorium issued by Governor Inslee is unique from the other three moratoriums. In all three instances, the other moratoriums were issued by granting a temporary reprieve to a specific individual for a set amount of time - whether that time frame be until certain evidence is provided or until a certain governor is out of office - whereas the moratorium 
by Governor Inslee was issued without granting a specific reprieve to anyone. Governor Inslee stated, “...I have decided to impose a moratorium on executions while I'm Governor of the state of Washington" and that, "If a death penalty case comes to my desk for action, I will issue a reprieve" (State of Washington Office of the Governor, 2014). The moratorium announced by Governor Inslee is different than the three other moratoriums to be discussed because it does not grant a reprieve to a specific individual but it instead promises that reprieves will be issued when necessary. This moratorium is also different because it is the only instance where a governor directly states he is imposing a moratorium.

Similar to the State of Washington, the State of Colorado's Supreme Court has not heard arguments or issued an opinion on Governor Hickenlooper's moratorium. Unlike Governor Inslee, Governor Hickenlooper initiated the current Colorado moratorium by granting a temporary reprieve to a specific death row inmate. Nathan J. Dunlap (Offender No. 89148) was convicted of four first-degree murder charges and was sentenced to die in 2013 (Hickenlooper, 2013). Governor Hickenlooper issued the temporary reprieve for a multitude of reasons not specific to Dunlap. Governor Hickenlooper throughout his executive order refers to Dunlap as Offender No. 89148 either as a way to limit attention to Dunlap or as a way to stress that the reprieve is issued not because of Dunlap specifically but because of factors outside of Dunlap's control. Governor Hickenlooper explained, "Because the question is about the use of the death penalty itself, and not about Offender No. 89148, I have opted to grant a reprieve and not clemency in this case." (Hickenlooper, 2013). Governor Hickenlooper's reprieve of Dunlap, though granted to a specific individual, initiates the Colorado Moratorium because of the reasons stated above.

Summary of the Oregon Moratorium and Haugen v. Kitzhaber (2013): 
The moratorium that is currently in place in the State of Oregon was initiated in November 2011 (“Gov. John Kitzhaber of Oregon declares a moratorium on all executions | Death Penalty Information Center," 2011). This moratorium was the first of the four moratoriums ${ }^{25}$ being analyzed. The Oregon moratorium is not only significant because it was the first one in this group to be issued, but it also is the first moratorium to be reviewed by the state supreme court; it later became an important foundation for Pennsylvania’s Supreme Court.

Governor Kitzhaber, similar to Governor Hickenlooper of Colorado, started the current moratorium in Oregon by issuing a temporary reprieve for Gary Haugen (“Gov. John Kitzhaber of Oregon declares a moratorium on all executions | Death Penalty Information Center,” 2011). Haugen volunteered to be executed and waived all of his rights to appeal. Nevertheless Governor Kitzhaber granted him an unwanted temporary reprieve because, as the Governor said, he, "simply [could not] participate once again in something I believe to be morally wrong." ("Gov. John Kitzhaber of Oregon declares a moratorium on all executions | Death Penalty Information Center," 2011). Furthermore, Governor Kitzhaber argued that "The death penalty as practiced in Oregon is neither fair nor just; and it is not swift or certain. It is not applied equally to all" (“Gov. John Kitzhaber of Oregon declares a moratorium on all executions | Death Penalty Information Center,” 2011). Governor Kitzhaber's reprieve of Haugen initiated the current moratorium. Even though Governor Kitzhaber did not directly state that he was issuing a blanket moratorium, it became clear that Governor Kitzhaber would not sign the death warrant of any inmate. Similar to Governor Hickenlooper, Governor Kitzhaber issued Haugen's temporary

\footnotetext{
${ }^{25}$ There have been, however, other moratoriums that have occurred before the Oregon Moratorium. Moratoriums like the one issued by Governor Ryan from Illinois will be used to give historical understanding but will not be analyzed in this paper because the moratorium is no longer in place as Illinois has abolished the death penalty.
} 
reprieve not because of something specific to Haugen or his case but instead because of issues with the overall death penalty.

Unlike the previous two moratoriums discussed, the moratorium initiated by Governor Kitzhaber was challenged by death row inmate Gary Haugen; Gary Haugen did not want a reprieve. Haugen's complaint was initially heard that the state Court of Appeals which ruled in his favor. In response, Governor Kitzhaber and the Attorney General filed a brief for the Oregon Supreme Court to review the matter. In the first brief filed, titled Brief on the Merits of Appellant, John Kitzhaber, Governor of the State of Oregon, Governor Kitzhaber argued that the power to grant clemency has always been "untethered and unfettered by any concomitant requirement that to be valid, the reprieve must be accepted." (Rosenblum, Joyce, \& Hogue, 2012). Throughout the initial brief, Governor Kitzhaber continuously argued that "An inmate simply possesses no power...to force his government to execute him." (Rosenblum et al., 2012). Additionally, the Oregon Constitution in Article V section 14 contains "no explicit requirement that to be valid, a reprieve must be accepted.” (Rosenblum et al., 2012). Similarly, the historical understanding of clemency was never dependent on "how the grant of the reprieve might be viewed by the person receiving it" but was instead a form of mercy issued from one individual to another (Rosenblum et al., 2012). The framers of the nation did not require that for an act of clemency to be valid that the recipient must accept it (Rosenblum et al., 2012).

Kitzhaber further argued that the case law, from the precedents established by the United States Supreme Court and the Oregon Supreme Court, does not establish that acceptance of a reprieve is necessary for the reprieve to be valid. Citing United States v. Wilson (32 US 150, 8 L. Ed. 640 (1833)), Kitzhaber argued that, though the case touches on the issue of clemency power and acceptance, it is not applicable to this situation because it applied before a conviction had 
occurred. Kitzhaber further argued that no state case law or federal case law suggests that the power to issue forms of clemency is as narrow as inmate Haugen is arguing. There is ample case law that states the opposite actually; the case law throughout the nation has only reaffirmed that the power to grant clemency was broad and expansive (Rosenblum et al., 2012). In Biddle v. Perovich (1927), the United States Supreme Court determined that power to grant clemency was broad and that, if a form of clemency was required to be accepted, it would "improperly infringe upon the President's power" (Rosenblum et al., 2012). Likewise, no Oregon court has held "that a beneficiary possesses the power to reject an unconditional reprieve and force the governor to put him to death." (Rosenblum et al., 2012). The only instances in state and federal case law where an acceptance was required was in instances of conditional pardons or reprieves. Kitzhaber concludes that the reprieve issued does not contradict any of the preexisting case law and is thus valid.

In the answering brief on the merits of respondent Gary D. Haugen, through attorney Harrison Latto, described the reprieve granted by Governor Kitzhaber as "ostensible" and "legally ineffective to half plaintiff's executions" (Latto, 2012). Haugen argued that the reprieve was ineffective for either two reasons: first, because the reprieve to be effective "has to be accepted by the intended recipient"; second, the reprieve being issued here was not a technical reprieve because it did not last for a definite period of time and "because it was issued not for the purpose of allowing certain circumstances to pass, but as an attempted nullification of certain laws" (Latto, 2012).

To support Haugen's argument that a form of clemency must be accepted in order for it to be effective, Haugen cited cases from both the State of Oregon and the United States Supreme Court. In Oregon Supreme Court Case Carpenter v. Lord (1918), Haugen pointed out that the 
court ruled that governors may issue pardons "by virtue of his constitutional power" but "even that is not effective unless it is accepted by the prisoner to whom the pardon is offered" (Latto, 2012). In Bollinger v. Board of Parole (1999), Haugen addressed that the Oregon Supreme Court decided that, "an inmate could elect to reject an offer of parole and remain in prison until the expiration of his sentence" (Latto, 2012). Similarly, Haugen cited the United States Supreme Court Case United States v. Wilson (1833) where the United States Supreme Court determined that a pardon, "may then be rejected by the person to whom it is tendered; and if it be rejected, we have discovered no power in a court to force it on him" (Latto, 2012). Haugen additionally pointed out that there is limited case law on this subject because the majority of inmates want some form of clemency, thus it is unlikely that they would reject the clemency being offered to them. Throughout the answering brief, Haugen argued that the previously discussed court opinions should not only apply to conditional forms of clemency but to all instances of clemency. Haugen further argued that, "to force something upon someone who does not want it is not an act of 'grace or favor,' which suggests something motivated by good will toward the intended beneficiary; an act of benevolence that the recipient does not want is simply a contradiction in terms" (Latto, 2012). Haugen's second argument is that the reprieve being issued is not a technical reprieve because it is issued for an indefinite amount of time. Citing In re Petition of Dortmitzer (1926), Haugen argued that the Oregon Supreme Court in this decision distinguished between reprieves and pardons by concluding that a reprieve is "the withdrawing of a sentence for an interval of time whereby the execution is suspended" (Latto, 2012).

Haugen enhances these points by arguing that the Governor has not provided enough evidence to overturn pre-existing precedents. First, Haugen argues that the current precedents have been consistent over a long period of time (Latto, 2012). Second, if clemency is to be 
viewed as a form of mercy from the Governor, then it cannot be "forced upon an unwilling recipient." (Latto, 2012). Third, as the United States Supreme Court recognized in Biddle v. Perovich (1927) life imprisonment is "a different kind of punishment than death" and that sentence could not be imposed on an inmate through commutation without the inmate's consent (Latto, 2012). Fourth, the reprieve granted is not specific to Haugen but is instead implemented to combat systemic issues and therefore makes this case an unusual one to depart from precedent (Latto, 2012).

Haugen in his initial brief also claims that this reprieve, if constitutional, would be a form of cruel and unusual punishment on inmates, and thus is an eighth amendment violation of the United States Constitution. Haugen argues that this reprieve lacks penological justification, which the Supreme Court has deemed necessary throughout multiple $\operatorname{cases}^{26}$ for sentences. The punishment that has been put in place against Haugen is only worsened and cruel due to the “indefinite, prolonged period of waiting without knowing when or whether he will be put to death" (Latto, 2012). Haugen additionally argues that this delay is cruel and unusual because it is not a delay he is initiating - this delay is caused "by the state against the prisoner's will." (Latto, 2012). Haugen builds on this argument by explaining that this reprieve also violates the Fourteenth Amendment. Haugen argued that ignoring his wishes strips him of one of the only liberties he has left.

Haugen then shifts his argument to analyze how Governor Kitzhaber's reprieve, in his opinion, violates the Oregon Constitution. First, Haugen argues that this reprieve does not match any of the forms of clemency granted to the governor through Article V Section 14 (pardon,

\footnotetext{
${ }^{26}$ Haugen references the following Supreme Court cases when making this point: Farmer v. Brennan (1994), Graham v. Florida (2010), Gregg v. Georgia (1976), Miller v. Alabama, (2012), and Roper v. Simmons (2005).
} 
reprieve, or commutation) and, as a result, is unconstitutional. Haugen distinguishes Governor Kitzhaber's reprieve from normal reprieves by pointing out ways this reprieve does not match the established pattern of reprieves:

The reprieve lacks an expiration date, and so lasts for an indefinite, rather than definite period of time. Moreover, the ostensible reprieve was granted, not to allow a circumstance to change or to enable Mr. Haugen to seek some legal relief, but with the intention that his sentence will never be carried out; not by any actual clemency granted by Governor Kitzhaber, but by what he hopes will be the abolition of the death penalty by the Legislative Assembly, or the People. The reprieve, despite its label, is actually an attempted suspension of the operation of certain laws, concerning which the Governor has misgivings. (Latto, 2012)

Haugen further argued that because this reprieve lacks the "essential characteristics" of a reprieve it is not legal a reprieve and is instead an "attempted suspension of the operation of certain of our State's laws." (Latto, 2012). Haugen argued that this action instead violates Article V section 10 of the Oregon constitution which calls that the governor "shall take care that the Laws be faithfully executed" (Or. Const. Art V §10). Article 1 Section 22 of the Oregon Constitution also states that "operation of the laws shall never be suspended, except by the Authority of the Legislative Assembly." (Or. Const. Art I §22). As a result, Haugen argued that “Governor Kitzhaber's reprieve, especially in the light of his broader moratorium on the carrying out of any executions during his service as Governor, amounts to a 'suspension' of certain laws..." (Latto, 2012). Haugen argued that this reprieve is actually a "suspension of certain laws, rather than a suspension of a sentence" (Latto, 2012). This is proven, according to Haugen, by the fact that this reprieve lacks a time frame. Haugen furthermore argued that if the supreme court rules in the favor of the Governor it would mean that "the Governor is not obliged to 'faithfully execute' a certain penal law, if he believes the law is not being carried out fairly, and would permit him to 'suspend' the operation of that same law." (Latto, 2012). It is further important to point out that the death penalty is written into the Oregon Constitution; Article I §40 
of the Constitution states that the penalty for aggravated murder "shall be death upon unanimous affirmative jury findings as defined by law..." (Or. Con. Art I §40). Haugen argued that because the death penalty is explicitly written into the Oregon Constitution any action to suspend the operation of the law would also be in contradiction to the constitution (Latto, 2012). Haugen concludes his brief by requesting that the Oregon Supreme court determine the threshold for what is and what is not a reprieve and rule that the reprieve issued by Governor Kitzhaber is unconstitutional. (Latto, 2012).

In response to the brief filed by Haugen's attorney, Governor Kitzhaber submitted a reply brief titled, Reply Brief. This reprieve responds to the claims through Haugen's argument that “(1) the Governor's understanding of the history and case law...is fundamentally flawed...; (2) the Governor's reprieve in this case is invalid because it fails to specify a specific duration; and (3) the Governor's reprieve constitutes cruel and unusual punishment..." (Rosenblum, Joyce, \& Hogue, 2013). Here, Kitzhaber argued that the case law cited by Haugen does not apply to reprieves but instead is applicable to pardons. "Courts have been inclined - for various reasons, sometimes unexplained ones - to conclude that a pardon must be accepted. That may derive from the fact that a pardon, unlike a commutation or reprieve, assumes one's guilt and, as such, creates at least an implicit condition that a grantee must accept." (Rosenblum et al., 2013). The case law, like Burdick v. United States (1915) does not apply to the reprieve issued by Governor Kitzhaber because it is not a pardon that is being issued. Governor Kitzhaber argued that "Commutations and reprieves, in contrast, relate not to one's guilt but rather to one's sentence." (Rosenblum et al., 2013).

The temporary reprieve also, as argued by Governor Kitzhaber, does not violate the Eighth Amendment. There is no case law that "holds that the uncertainty of knowing a precise 
date of execution is, in and of itself, an Eighth Amendment violation." (Rosenblum et al., 2013). Governor Kitzhaber acknowledged that while the Supreme Court has "left open the possibility that prolonged stays on death row and the concomitant uncertainty about where an execution might occur may mount to cruel and unusual punishment" there is no majority opinion or decision that has established this precedence (Rosenblum et al., 2013). There is nothing, according to Governor Kitzhaber, that established if Haugen's unknown execution date constitutes cruel and unusual punishment.

Governor Kitzhaber further argued that the reprieve is valid because it is not for an indefinite amount of time and because the reasoning of the reprieve does not matter. Governor Kitzhaber argued that "this court is without the authority to review the reasons that the Governor granted the reprieve. Where the Governor has acted within the authority conferred on him by Article V, section 14, to grant Haugen a reprieve, his reasons for doing so are not subject to further judicial review." (Rosenblum et al., 2013). Citing the court decision in Eacret v. Holmes (1958), Governor Kitzhaber pointed out that the court ruled, "The courts have no authority to inquire into the reasons or motives which may actuate the Governor in exercising the power, nor can they decline to give effect to a pardon for an abuse of discretion." (Rosenblum et al., 2013). Governor Kitzhaber argued that, "Article V, section 14, thus empowers the Governor to decide whether to grant clemency and to determine what kind of clemency to grant. His reasons for doing so are solely within his discretion and the purview of the executive branch." (Rosenblum et al., 2013). Furthermore, the Governor's reprieve is not an indefinite reprieve because it does lack an expiration date; "the end of the Governor's term in office" (Rosenblum et al., 2013). The reprieve granted to Haugen is not a suspension of laws because it only suspends the "execution of Haugen's sentence for a temporary period of time.” (Rosenblum et al., 2013). The reprieve 
issued by Governor Kitzhaber does not change or suspend Article I, section 40 of the Oregon constitution; individuals can still receive the penalty of aggravated murder (Rosenblum et al., 2013). Governor Kitzhaber concluded his argument by stressing that as Governor, he possesses the authority to "temporarily suspend an individual sentence" and that the suspension of the sentence is not equivalent to a suspension of law (Rosenblum et al., 2013).

The Oregon Supreme court on June 20, 2013, in a unanimous decision, ruled in favor of Governor Kitzhaber. Chief Justice Tom Balmer wrote the majority opinion. The court first determined that because the office of the governor is an "equal branch of government" the court must not "'assume the power to question the action of the executive" (Haugen v. Kitzhaber, 2013). The court however, in this case, has the authority to determine the threshold of what qualifies as a reprieve; the Governor similarly agreed that the court had the authority to decide this case but does not have the authority to review the reasoning for the reprieve. (Haugen $v$. Kitzhaber, 2013). The court in this decision only discussed what constitutes a reprieve. First, in analyzing the definition of the word reprieve, the court recognized that none of the definitions provided that, "Nothing inherent in the word 'reprieve' requires the recipient's acceptance for the reprieve to be effective." (Haugen v. Kitzhaber, 2013). The court additionally argued that the reprieve issued does have an expiration date. Though the end of the Governor's term "could occur at different points in time" his service will still end, and when it does "Haugen's sentence will be reinstated."27 (Haugen v. Kitzhaber, 2013). The court additionally agreed that the Governor's issued reprieve suspends the sentence, not the laws (Haugen v. Kitzhaber, 2013). The court found that in the case law for Oregon requires a reprieve to be accepted nor does any of the

\footnotetext{
${ }^{27}$ The Oregon Supreme Court also stated "When the reprieve expires at the end of the Governor's service, Haugen's sentence will be executed unless the Governor's successor grants another act of clemency." (Haugen v. Kitzhaber, 2013). This is relevant because Governor Brown, the successor of Governor Kitzhaber, has maintained the moratorium initiated by Governor Kitzhaber.
} 
federal case law relate directly to this case (Haugen v. Kitzhaber, 2013). The court additionally rejected the argument that the duration of sentence is a form of cruel and unusual punishment since there is no established precedent to follow (Haugen v. Kitzhaber, 2013).

Summary of Pennsylvania Moratorium and Commonwealth v. Williams (2015):

Governor Tom Wolf issued a temporary moratorium for inmate Terrence Williams who had a scheduled execution for March 4, 2015 (Wolf, 2015). The reprieve was not rejected by Williams likely because Williams did not volunteer to be executed like inmate Gary Haugen of Oregon did. Governor Wolf, in his memorandum, discussed that he issued this reprieve and all future reprieves in response to the "significant and widely recognized defects" in the Pennsylvania death penalty system and to give the chance for the Pennsylvania Task Force and Advisory Committee on Capital Punishment ${ }^{28}$ to recommend any changes to the Pennsylvania death penalty system (Wolf, 2015). This moratorium, unlike the one issued by Governor Kitzhaber, was determined to end once the Task Force provided the Governor with its report. The reprieve issued by Governor Wolf was accepted by inmate Terrence Williams, unlike the reprieve issued by Governor Kitzhaber in Oregon. The Pennsylvania District Attorneys Association, along with the Speaker of the House of Representatives of Pennsylvania and the President Pro Tempore of the Senate of Pennsylvania ${ }^{29}$, representing the Commonwealth of Pennsylvania, filed suit against the Governor and inmate Williams for the reprieve.

\footnotetext{
${ }^{28}$ Throughout this analysis, the Pennsylvania Task Force and Advisory Committee on Capital Punishment will be referred to as the Task Force.

${ }^{29}$ As a group, this analysis will refer to the Pennsylvania District Attorneys Association, the Speaker of the Pennsylvania House of Representatives, and the President Pro Tempore of the Pennsylvania Senate as the Commonwealth since they are collectively filing suit against Governor Tom Wolf and inmate Terrance Williams as the Commonwealth of Pennsylvania.
} 
Instead of the lower courts reviewing this suit like was initially seen in the Haugen $v$. Kitzhaber case, the Pennsylvania District Attorneys Association ${ }^{30}$ filed suit directly to the Pennsylvania Supreme Court under the court's King's Bench jurisdiction. King's Bench jurisdiction in Pennsylvania gives the Pennsylvania Supreme Court "superintendency over all inferior courts in matters ranging from powers of rule-making to plenary jurisdiction." (Scherer, 1994). King's Bench jurisdiction was necessary here, according to the Pennsylvania DDA, because it was "imperative that this Court define the scope of the Governor's reprieve power under the Constitution.” (Kichline, 2015). The Pennsylvania DDA argued that the Governor's reprieve was in violation of the Constitution of Pennsylvania because the Governor was unilaterally upsetting the imposition of the death penalty, violated the constitutional provision that only allows for the legislature to suspend laws, and was in violation of the Governor's duty to make sure the laws are faithfully executed (Kichline, 2015). The Pennsylvania DDA additionally argued that the Governor was issuing this reprieve as a way to promote his personal policy against the death penalty because he had campaigned that he would institute a moratorium once elected governor (Kichline, 2015).

Similar to the argument made by inmate Haugen in Haugen v. Kitzhaber, the Pennsylvania DDA argued that the reprieve being utilized here was not truly a reprieve. At the time of the formation of the Pennsylvania Constitution, the founders utilized the English common law when determining the governor's clemency powers. The English common law defined a reprieve as a temporary pause of a sentence that was only applicable for a finite amount of time in certain situations like providing time for an inmate to apply for a pardon, an inmate (female) is pregnant and needs time before the judgement is executed, or when the

\footnotetext{
${ }^{30}$ The Pennsylvania District Attorneys Association will also be referred to as the Pennsylvania DDA.
} 
convict has become "temporarily insane" (Kichline, 2015). The reprieve that Governor Wolf issued for inmate Williams, the Pennsylvania DDA argued, is not for a finite period of time and is not for a recognized common law reason (Kichline, 2015).

The Pennsylvania DDA claimed that the Governor's reprieve violates multiple provisions of the Pennsylvania Constitution. Utilizing the same argument for each provision, the Pennsylvania DDA claimed that the governor's reprieve violates Article IV, Section 9, Article I, Section 12, and Article IV, Section 2 of the constitution (Kichline, 2015). The Pennsylvania DDA, however, spends the majority of their initial brief focused on how this reprieve violates Article IV, Section 9 of the Pennsylvania Constitution. They argued that the Governor is in violation of Article IV, Section 9 of the Pennsylvania Constitution. Throughout the history of Pennsylvania, the joint power between the Governor and the Board of Pardons has been used to decentralize the universal power of clemency to the Governor. The Pennsylvania DDA further argued that this relationship signifies the desire of the citizens of Pennsylvania to prevent unilateral decisions regarding criminal sentences to the death penalty to be made, though Article IV, Section 9 does not require the Board of Pardons to review reprieves being granted by the Governor (Kichline, 2015). The Pennsylvania DDA continuously stressed that this reprieve does not match the definition of a reprieve because it is not for a finite period of time and conflicts with the English common law understanding of a reprieve. The Pennsylvania DDA expressed that the Governor is in violation of the Pennsylvania Constitution because it is not issued based on specific reasons to inmate Williams, instead the reprieve is issued for systemic reasons (Kichline, 2015). 
The Speaker of the Pennsylvania House of Representatives ${ }^{31}$ and the President Pro Tempore of the Senate of Pennsylvania ${ }^{32}$ also issued an amici curiae brief supporting the brief written by the Pennsylvania DDA and in support of the Commonwealth of Pennsylvania. The Speaker of the House and the President Pro Tempore argued that, "The premise underlying both the Republic and the Commonwealth, that all authority ultimately resides in the People as expressed through their Constitution, stands in stark contrast to Governor Wolf's unilaterally announced moratorium on the death penalty." (Corey, Mann, Dymek, Crompton, \& Gerdes, 2015). Similar to the brief filed by the Pennsylvania DDA, the Speaker of the House and the President Pro Tempore argued that the Governor does not have the constitutional right to issue this broad, unilateral reprieve because it conflicts with the role of the Board of Pardons in relation to the Governor's clemency power (Corey et al., 2015). The Speaker of the House and the President Pro Tempore further argued that the court must conclude that, "The Governor cannot forsake his obligation to 'take care that the laws be faithfully executed' by contending that the failure to do what the law says that he 'shall' do, constitutes the performance of affirmative and definitive action known to the law as a reprieve." (Corey et al., 2015). They argued that the Governor could not issue reprieves that violate his or her other constitutional duties.

In response, the Governor of Pennsylvania, Governor Tom Wolf, filed a brief countering the Commonwealth's argument against the reprieve he issued for inmate Terrence Williams. First, the Governor disagreed with the Commonwealth's claim that the Supreme Court in this situation has the authority to claim King's Bench jurisdiction. The Governor stressed that the

\footnotetext{
31 The Speaker of the Pennsylvania House of Representatives will be referred to as the Speaker of the House.

32 The President Pro Tempore of the Senate of Pennsylvania will be referred to as the President Pro Tempore.
} 
"Governor most decidedly is not an 'inferior tribunal' over which this Court has a 'power of general superintendency."' (Smyler, Moulton Jr., Lehr, \& Concannon, 2015) Similar to the argument that Governor Kitzhaber made in his brief to the Oregon Supreme Court, Governor Wolf firmly pointed out that the executive branch is an equal branch of government to the Pennsylvania Supreme Court; the position of the Governor is not beneath the Pennsylvania Supreme Court but is instead equal to the Pennsylvania Supreme Court. Governor Wolf likewise argued that the Pennsylvania Supreme Court could review this matter under the extraordinary jurisdiction circumstance to avoid an "unprecedented and constitutionally untenable assumption of jurisdiction over the Governor and exercise of executive power..." (Smyler et al., 2015). Referencing Pennsylvania Supreme Court case Stroup v. Kapleau (1973), Governor Wolf argued that “...[A] Governor's executive action must be upheld 'unless it clearly, palpably, and plainly violates the constitution,' and '[a]ny doubts are to be solved in favor of find of constitutionality." (Smyler et al., 2015). Therefore, the Governor argued that the Pennsylvania Supreme Court should follow this precedent established under the Stroup v. Kapleau decision.

Governor Wolf countered the Commonwealth's primary argument that Article IV, Section 9 prevents the governor from issuing reprieves of this nature. Article IV, Section 9 , Governor Wolf argued, "expressly and unqualifiedly grants to the Governor the sole and exclusive executive power 'to grant reprieves."' (Smyler et al., 2015). According to Governor Wolf, the reprieve issued to Williams was to "only stay the execution temporarily" and that "Williams remains convicted of first degree murder and duly sentenced by a court of this Commonwealth to die...Williams' status as convicted and sentenced capital offense murderer has not been altered by the Governor's temporary reprieve of the actual administration of Williams' execution." (Smyler et al., 2015). The Pennsylvania Constitution in Article IV, 
Section 9 does not restrict the Governor's authority to issue reprieves like it does commutations and pardons. Instead, Article IV, Section 9 gives the Governor the constitutional power to issue reprieves that are not only "express" and "unlimited" but also the ability to issue reprieves that stand "without regulation by any other body or official of government, including the General Assembly and the courts." (Smyler et al., 2015). The only restrictions present on the governor's ability to issue reprieves, Governor Wolf argued, is that the reprieves must operate in criminal cases and cannot be used in cases of impeachment (Smyler et al., 2015). The Governor additionally argued that, historically, the citizens of the Commonwealth of Pennsylvania have never restricted the governor's ability to issue reprieves (Smyler et al., 2015). Governor Wolf further countered the Commonwealth's argument that the reprieve issued here is not a reprieve by addressing the components of his reprieve that are typical of reprieves. First, the governor pointed out that this reprieve is tied to a "particular proceeding in which the offender is seeking relief." (Smyler et al., 2015). Second, Governor Wolf argued that this reprieve is limited in time (Smyler et al., 2015). Governor Wolf stressed that "to suggest that reprieves are ordinarily granted for a particular set of reasons in no way implies that they may be granted only for those reasons..." (Smyler et al., 2015).

Inmate Terrance Williams, through his attorneys Shawn Nolan and Timothy Kane, filed a similar brief to the one that Governor Wolf filed. Williams contradicts the Commonwealth's argument, similar to Governor Wolf, and argued that it is not appropriate for the Pennsylvania Supreme Court to use their King's Bench authority because this is a unilateral action by the executive, which is a sister branch to the Court (Nolan \& Kane, 2015). Williams argued that in “this Court's nearly 300-year existence, it has never interfered with a reprieve" and that the Governor's power to grant reprieves has never been restricted (Nolan \& Kane, 2015). Williams 
provided a detailed historical analysis, and continuously pointed out that citizens in the state of Pennsylvania have never once limited the Governor's power to issue reprieves (Nolan \& Kane, 2015). Williams discredited the Commonwealth's argument, first by addressing that the plain language of the Pennsylvania Constitution means that the Governor has the constitutional power to issue reprieves (Nolan \& Kane, 2015). Second, Williams argued that there is no historical precedent that would persuade the Pennsylvania Supreme Court to rule in favor of the Commonwealth (Nolan \& Kane, 2015). Third, Williams argued that there is no persuasive authority in either the Pennsylvania jurisprudence or in the federal jurisprudence for this matter; the only court to have reviewed a case like this was the Oregon Supreme Court in Haugen v. Kitzhaber where the court ruled in favor of Governor Kitzhaber (Nolan \& Kane, 2015). Williams concluded that the Pennsylvania Supreme Court is obligated to uphold the preexisting precedence established in the state, or the lack thereof, and rule in favor of Governor Wolf's reprieve (Nolan \& Kane, 2015).

The Commonwealth issued two Briefs in Reply to both inmate Williams and Governor Wolf. In both reply briefs, the Commonwealth addresses their main argumentative points. The Commonwealth claims that though the Pennsylvania Constitution does not explicitly limit Governor Wolf's reprieve powers, a reprieve of this nature is not normal and is the Governor using broad, unilateral powers to affect policy (Burns Jr., Eisenberg, McCann, \& Williams, 2015a) (Burns Jr., Eisenberg, McCann, \& Williams, 2015b). In response to inmate Williams’ brief, the Commonwealth argued that the "moratorium" issued by the Governor is "unending" and "perpetual" (Burns Jr. et al., 2015a). The Commonwealth argued that, "The defining difference between a reprieve and the Governor's moratorium is that no one can say when, how, or even if, his moratorium will ever end." (Burns Jr. et al., 2015a). Comparably, in the 
Commonwealths brief in reply to Governor Wolf, the Commonwealth stressed that the reprieve issued by Governor Wolf is in violation of the Pennsylvania Constitution because it is "indefinite" (Burns Jr. et al., 2015b).

The Pennsylvania Supreme Court on December 21, 2015, in a unanimous decision ${ }^{33}$, sided with Governor Wolf and inmate Williams that this form a reprieve was constitutional. The Court first determined that, in this case, it was appropriate for them to use their King's Bench jurisdiction because the issue is of extreme public importance (Commonwealth of Pennsylvania. v. Williams, 2015). Though the Pennsylvania Supreme Court agreed with the Commonwealth's position that this case falls under the courts King's Bench powers, they disagree with the Commonwealth on the constitutionality of the reprieve issued by Governor Wolf. First, relying on the English common law understanding, the court recognized that historically, there was no restrictions on the power to grant reprieves (Commonwealth of Pennsylvania. v. Williams, 2015). This power has never been restricted or regulated by the citizens of Pennsylvania or during the multiple constitutional conventions throughout the history of the state (Commonwealth of Pennsylvania. v. Williams, 2015). The Court further argued that the Governor is not required to provide reasoning for the reprieve, like the Commonwealth initially argued (Commonwealth of Pennsylvania. v. Williams, 2015). The Court additionally agreed with Governor Wolf and inmate Williams that this reprieve is not a suspension of law, but is instead a delay of the execution (Commonwealth of Pennsylvania. v. Williams, 2015). The Court firmly concluded that this reprieve is temporary in nature and is not considered "permanent" just because "it is unclear precisely when it will expire." (Commonwealth of Pennsylvania. v. Williams, 2015).

\footnotetext{
33 Though the opinion was unanimous, there was one concurring opinion. Therefore, there is a difference between the Oregon Supreme Court Decision and the Pennsylvania Supreme Court decision.
} 
A voice of caution is offered in the concurring opinion written by Justice Correale Stevens. First, Justice Stevens highlights that the actions of inmate Williams and the horrific crime he committed have become "secondary to philosophic discussion about the viability of the death penalty." (Commonwealth of Pennsylvania. v. Williams, 2015). Justice Stevens wrote a separate, concurring opinion, to express how this decision "does not encourage or validate executive branch nullification of lawfully enacted statutes." (Commonwealth of Pennsylvania. $v$. Williams, 2015). Quoting John Adams, Justice Stevens reminds the Governor and the Legislature, "we are a 'government of laws, not of men." (Commonwealth of Pennsylvania. v. Williams, 2015). Justice Stevens also is concerned that, since this reprieve is in effect until recommendations are "satisfactorily" addressed it could evolve into something that is not temporary, especially since the Task Force, as of 2015, had been in place for four years and it had been thirty-one years since Terrance Williams committed his horrific crimes (Commonwealth of Pennsylvania. v. Williams, 2015). Lastly, Justice Stevens stressed that changes to the death penalty laws in Pennsylvania should come from the legislature or the citizens (Commonwealth of Pennsylvania. v. Williams, 2015).

\section{Analysis:}

Governor's clemency powers range from state to state and vary in degrees of power. State constitutions, like the ones in Oregon, Washington, and Colorado, give almost total sovereignty over issues of clemency to their governors, whereas constitutions like the one in Pennsylvania limit when a governor can unilaterally use this clemency power. The range of clemency power granted to governors allows them to issue these blanket moratoriums. Restrictions can be put in place to limit these powers, as seen in Pennsylvania; however, these restrictions have historically only been on the power to grant pardons or commutations because 
they are more serious. The power to grant reprieves, because they only delay the sentence of the inmate, has historically been less restricted. Thus, the lack of current or historical restrictions on this specific power do not suggest that these moratoriums are unconstitutional. Furthermore, these moratoriums are constitutional because they fall within the understood definition of a reprieve.

As seen in the examples of Haugen v. Kitzhaber in Oregon and Commonwealth $v$. Williams in Pennsylvania, state supreme courts have been apprehensive in restricting a governor's power to issue reprieves. The historical roots of a governor's power to issue reprieves, the current dynamic of the death penalty, state supreme court interpretations of governor's reprieve powers, and the United States Supreme Court's lack of guidance in this matter allow governors to use their power this broadly. Though this power could be limited by constitutional amendments, overturning current state supreme court decisions, or by a decision by the United States Supreme Court, this power currently has been determined to be constitutionally valid when used in broad, sweeping forms.

Governors are allowed to issue these universal moratoriums on the death penalty because there are no textual limitations in their state constitutions or in the United States Constitution that prevents this. In order for these moratoriums, which are essentially reprieves that apply to all inmates on death row, there must be a textual violation of either the United States Constitution or the individual constitutions. Article V, Section 14, of the Oregon Constitution only limits the Governor's clemency power in instances of impeachments or treasons (Or. Const. Art. V. §14). Article IV, section 9, of the Pennsylvania Constitution only restricts the Governor's power to grant clemency in instances of pardons and commutations, not reprieves (Pa. Const. Art. IV §9). The Washington Constitution barely limits the governor's clemency power at all (Wa. Const. 
Art. III §9) and the Colorado Constitution limits the governor's clemency powers in the same way the Oregon Constitution does (Co. Const. Art. IV §7). The lack of textual restrictions in these state constitutions prevent the state supreme courts from ruling that the reprieves issued by these governors are unconstitutional. Because there are no textual restriction in these individual constitutions, these moratoriums have not been ruled as unconstitutional.

Moreover, the United States Constitution does not restrict the President's ability to grant reprieves as well. Article II, Section 2, of the United States reads, "The President...shall have power to grant reprieves and pardons for offences against the United States, except in cases of impeachment.” (U.S. Con. Art II §2). The lack of textual restrictions on an executive’s power to grant reprieves both at the state and federal level prevents state supreme courts from ruling that the reprieves issued were unconstitutional. Thus, the moratoriums issued do not textually violate their respective state constitution or the United States Constitution because they were established through reprieves. The judiciary at the state and federal level must follow their respective constitutions and the United States Constitution when determining if an action or law is in violation of the constitution. If the Oregon Supreme Court or the Pennsylvania Supreme Court ruled that these moratoriums were a violation of the state or federal constitution, it would be an overreach of judicial power.

As discussed extensively in the filing briefs for both Haugen v. Kitzhaber and Commonwealth $v$. Williams, there is no historical precedence that established the executives' power to issue reprieves has been constricted. Alexander Hamilton argued in Federalist 69 that the President "will resemble equally that of the King of Great Britain" in regard to his or her power to issue clemency (Hamilton, 1788b). The founding fathers envisioned the powers of the clemency given to the executive to be expansive, only limited in instances of impeachment. At 
the 1787 Constitutional Convention, the founders adopted the same English statute that granted the King the power to issue clemency as part of the President's powers in Article II; the only difference was a slight word change from "but his pardon shall not be pleadable in bar" to “exception in cases of impeachment" (Duker, 1977). During the founding of the nation, the Founding Fathers did not understand the power to issue reprieves to be limited. There is a lack of historical evidence to suggest that the Founding Fathers would have understood the power to grant clemency, especially in instances of reprieves, to be limited. The lack of federal historical evidence suggest that these moratoriums do not violate the well-established understanding of the power to grant reprieves.

Citizens of states like Oregon, Washington, and Colorado, though they joined the union later than Pennsylvania, followed the similar idea of broad clemency powers for the executive. As state constitutions have changed through either amendments or conventions, citizens of states seldom restrict the power of the governor to issue reprieves. For example, in the state of Pennsylvania, the state constitution had been amended in 1790, 1838, 1874, 1968 and 1997, and each time it was amended, there were no changes to the governor's power to issue reprieves (Smyler et al., 2015). Similarly, in the briefs filed for Haugen v. Kitzhaber, there was no historical evidence offered that the governor's power to issue a reprieve had ever been restricted. The lack of historical restrictions on executive clemency power, specifically the power to issue reprieves, fails to establish a pattern in which the court could easily follow. Therefore, there was no historical precedent that would have courts of these states to rule against their governor. Because these moratoriums are initiated as a reprieve it is hard for the state supreme courts' ability to rule that they are unconstitutional. If the state supreme courts ruled that these moratoriums were unconstitutional, it would result in the judiciary performing more like the 
legislature and would disrupt the balance between checks and balances. There is no historical evidence at either the federal or state level to suggest that these moratoriums are unconstitutional.

Both Governor Kitzhaber and Governor Wolf's actions are considered a reprieve because they only delay the imposition of a sentence and the lack of historical guidance also limits the state supreme courts from ruling against the governor. There have been no instances in English common law where a sovereign's reprieve power has been restricted nor have there been instances in American history where this has occurred. The Oregon Supreme Court recognized that, historically and currently, “The Governor's ability to grant clemency is a direct and complete check on specific actions of the judicial branch that is entrusted to the chief executive." (Haugen v. Kitzhaber, 2013). Similarly, there have been no instances where the citizens of Oregon have strictly defined what a reprieve is; there has been no establishment of a required time length or required acceptance for a reprieve to truly be a reprieve nor was there a requirement that the reprieve be specific to the individual (Haugen v. Kitzhaber, 2013). As a result, there is no evidence to support Haugen's argument that the reprieve issued does not technically count as a reprieve. The governor is allowed to issue reprieves, regardless of the reason. There is no restriction that determine when or why a governor is allowed to reprieve an inmate. Furthermore, the reprieve is established for a set period of time. Governor Kitzhaber reprieve matches the well understood nature of a reprieve. Therefore, the reprieve issued by Governor Kitzhaber is not a violation of the constitution and is a valid way of starting the current moratorium.

Both the Oregon Supreme Court and the Pennsylvania Supreme Court determined that governors and presidents "have granted reprieves for a wide range of reasons, including political, 
personal or private reasons, and that nothing suggested that a reprieve had to be granted for one specific reason.” (Wolf, 2015). Similarly, Governor Wolf's reprieve of Williams is valid because it is again issued for a set period of time. The period of time determined for Williams reprieve is more ambiguous than the reprieve established by Governor Kitzhaber. But this ambiguity does not make it unconstitutional because the reprieve is not set for an indefinite amount of time. Moreover, the reprieve issued by Governor Wolf is even more sound because it was requested by the Task Force. The lack of historical restrictions or limitations on the governor's reprieve power suggest that issuing reprieves this broad and expansive does not violate the constitution simply because it has never, historically, been an overreach of executive power. In addition, these moratoriums are issued in ways that match the historical pattern for establishing reprieves. Nothing about the technical nature of these reprieves differs them from previously issued reprieves. Thus, the moratoriums that result because of these reprieves are not an overreach of gubernatorial power.

The Supreme Court of the United States, like many other state supreme courts, has dealt with the matter of clemency powers, but mainly in relation to pardons or commutations, and not reprieves. For example, in the briefs filed for Haugen v. Kitzhaber (2013), cases like Biddle v. Perovich (1927), Burdick v. United States (1915), Ex parte Grossman (1925), and Ex parte Wells (1855), all dealt with issues surrounding an issued pardon or commutation; none of the cases dealt specifically with a reprieve. Pardons and commutations are more serious forms of clemency powers because they actually alter the inmates sentence. Though these cases dealt with the ability to issue pardons, the Supreme Court has continuously ruled that the executives power to grant pardons is "unlimited" and "cannot be fettered by any legislative restrictions." (Ex Parte Garland, 1866). This could be, in part, because reprieves are the least common form of clemency 
issued ("Clemency Statistics | PARDON | Department of Justice," 2018) or because a reprieve is the least extreme form of clemency an executive can issue it since it only delays the inevitable. The lack of federal case law regarding what an executive is allowed to do when utilizing their reprieve powers leaves the state supreme courts with little guidance. It can further be inferred, that because the United States Supreme Court has ruled that the power to issue pardons is unrestricted, that the power to issue reprieves is unrestricted as well. The unrestricted nature of a reprieve prevents these moratoriums from being viewed as violation of the United States Constitution.

The lack of federal case law has resulted in state courts, as demonstrated by the Supreme Court of Oregon and the Supreme Court of Pennsylvania, turned to their own existing case law. As seen with the lack of reprieve doctrine in federal case law, there is a minimal relationship between the preexisting case law regarding reprieves and the issue at hand. The lack of precedence in the case law left both the Oregon Supreme Court and the Pennsylvania Supreme Court no guidance for overturning the reprieves. Similarly, there were no glaring issue with these reprieves that violated any established federal case law on an executive's general clemency powers.

The moratoriums enacted are not a suspension of law. Instead, these moratoriums only delay the sentence of these inmates. Reprieves, under the legal definition, are the delay of the punishment of an inmate, not a delay of the actual law ("Reprieve | Definition of Reprieve by Merriam-Webster Law Dictionary,” 2018). Inmate Haugen argued that Governor Kitzhaber's moratorium violated the Oregon Constitution, specifically Article I, Section 22 of the Oregon Constitution which dictated that the "operation of laws shall never be suspended, except by the Authority of the Legislative Assembly." (Latto, 2012). Similar arguments were made by the 
Commonwealth of Pennsylvania. This argument was discredited by the Oregon Supreme Court and the Pennsylvania Supreme Court. The Oregon Supreme Court determined that the "reprieve suspends Haugen's sentence, rather than the laws." (Haugen v. Kitzhaber, 2013). The

Pennsylvania Supreme Court further determined that because the reprieve was temporary in nature, it did not violate other provisions of the Pennsylvania Constitution, like Article I, Section 12 which required that the laws be faithfully executed. (Commonwealth of Pennsylvania. $v$. Williams, 2015). The laws are still being executed; individuals are still being sentenced to death. The actual execution of the individual is delayed until either the governor leaves office, changes their mind, or sufficient evidence that the capital system works in these states is provided. If the governor was enacting a moratorium by pardoning all death row inmates or commuting the sentence of all death row inmates, there would be a stronger argument that these actions are a suspension of law. Because reprieves only delay a sentence, there is simply no way they could fully act as a suspension of law. Inmates are still sentenced to death; thus, the death penalty law is still in effect, there is just a delay on the actual date of execution.

Furthermore, the Oregon Constitution in Article I, Section 40 states that "the penalty for aggravated murder as defined by law shall be death upon unanimous affirmative jury finds as provided by law and otherwise shall be life imprisonment with minimum sentence as provided by law” (Or. Const. Art I §40). The Oregon Supreme Court determined, however, that the reprieve and moratorium issued by Governor Kitzhaber did not violate the Oregon Constitution. The reprieve issued does not prevent the sentence of the death penalty from being imposed, instead it delays the actual execution of the inmates. For example, two individuals, since the moratorium was first announced by Governor Kitzhaber, have been sentenced to death, and one individual has been sentenced to death again for the fourth time (Palombo et al., 2018). The 
moratorium does not prevent the constitutional provision Article I, Section 40 from being followed; juries still are able to sentence individuals to death and have sentenced people to death under this moratorium. Instead, the moratorium delays the actual execution of the defendant.

These moratoriums do delay the date of execution for these inmates, however, it is nothing compared to the delay these inmates face once they are sentenced to death. These inmates must go through an extensive appeal process before their death warrant is even presented to the governor. In Oregon, an inmate's sentence of death is automatically appealed to the Oregon Supreme Court which must review the case (Kaplan, Collins, \& Mayhew, 2016). Often times, as seen in Oregon, the Oregon Supreme Court finds errors with the original sentencing of these inmates and thus sends the decision back for resentencing. Inmates like Randy Guzek, Michael McDonnell, Robert Langley, Dayton Leroy Rogers, have all been sentenced and resentenced more than four times each (Kaplan et al., 2016). These inmates have the constitutional right to many more appeals than just the direct appeal to the state. ${ }^{34}$ As a result, the death penalty is very expensive and takes a very long time. The inmates previously listed have all been on Oregon's death row for close to thirty years and none have exhausted all of their appeal options. ${ }^{35}$ A gubernatorial moratorium does not delay executions as the exercise of their constitutional appeal rights does. In fact, because governors' terms are shorter than thirty years, it is likely that these moratoriums may not delay their executions at all since these moratoriums cease at the end of a governor's term of office.

\footnotetext{
${ }^{34}$ These inmates can appeal, for example, to the United States Supreme Court for Habeas Corpus Relief, or the state appeals court for Post-Conviction Relief (Kaplan, Collins, \& Mayhew, 2016).

${ }^{35}$ Inmates do have the option of waiving their rights to appeal, though this is typically after many years of being in prison or on death row, as seen through the example of Oregon death row inmate Gary Haugen (Palombo, Glanville, Haberman, \& Hernandez, 2018).
} 
Moratoriums, while initiated through the governor's ability to grant reprieves, are similar to executive orders. Executive orders are utilized by both the President of the United State and many state governors that are "declarations to government officials and administrative agencies that have the force of law and do not require legislation to take effect." (Cockerham \& Crew, 2017). Often times, they are used a temporary policies that can be undone by the next governor or president (Cockerham \& Crew, 2017). These moratoriums act as an executive order because they established a policy that the governor and the executive department of the state will follow. Though these executive orders are often viewed as unilateral policy actions, they are constitutional.

Additionally, the United States Supreme Court and state supreme courts often avoid ruling on the constitutionality of these executive orders because of the potential for these executive orders to fall under the political question doctrine. The political question doctrine determines if a case concerns a political question it is nonjusticiable and thus the court will not get involved. In the famous United States Supreme Court Case Baker v. Carr (1962), the court, besides ruling "one person, one vote" also determined when a case falls into the political question area. The Court determined that questions presented to the court that may fall under the political question doctrine are typically a function of the "separation of powers." (Baker v. Carr, 1962 $)^{36}$. Though the Oregon Supreme Court and the Pennsylvania Supreme Court issued opinions regarding these moratoriums, their decisions fall in line with the established political

\footnotetext{
${ }^{36}$ The court described a political question as "a textually demonstrable constitutional commitment of the issue to a coordinate political department; or a lack of judicially discoverable and manageable standards for resolving it; or the impossibility of deciding without an initial policy determination of a kind clearly for non judicial discretion; or the impossibility of a court's undertaking independent resolution without expressing lack of the respect due coordinate branches of government; or an unusual need for unquestioning adherence to a political decision already made; or the potentiality of embarrassment from multifarious pronouncements by various departments on one question." (Baker v. Carr, 1962).
} 
question doctrine protocol. The Governor's ability to grant clemency is a separation of powers issue and is a power the is textually granted to the Governor. If the Oregon Supreme Court or the Pennsylvania Supreme Court were to rule against the Governor in these cases, it would be an overreach of the courts' power and would place one branch of the government has over.

\section{Conclusion:}

So called moratoriums issued by Governor John Kitzhaber, Governor Kate Brown, Governor Tom Wolf, Governor Jay Inslee, and Governor John Hickenlooper are all constitutional uses of the governor's power to grant clemency. The moratoriums fall within the well understood definition of a reprieve, are issued for a definite period of time, and are issued in ways that match the historical pattern of a legal reprieve. These reprieves are issued reasons that are not specific to the inmate receiving the reprieve, the reasoning that the reprieve is issued does not matter and does not determine if the reprieve is constitutional or not. The decision by the Oregon Supreme Court and the Pennsylvania Supreme Court to uphold the constitutionality of these moratoriums follows not only the courts' precedents, but the United State Supreme Court's precedents, and the English common law understanding of reprieves. For these moratoriums to be deemed unconstitutional one of three things would either have to occur: The United States Supreme Court must deem any state moratorium on the death penalty as unconstitutional under the federal constitution; the state legislatures, or citizens would have to pass a state constitutional amendment to prevent these moratoriums from occurring; or the citizens of the United States would need to pass a federal constitutional amendment to prevent these moratoriums.

These moratoriums, issued by the Governors of Oregon, Pennsylvania, Washington, and Colorado, were clearly issued for political reasons. These reasons, however, do not affect the 
constitutionality of the moratoriums. They also reflect and reveal often long-standing debates and systemic problems with each states history of capital punishment. The death penalty was intended to be used for retribution and deterrence, but the systemic errors prevalent within the death penalties of each state make these "neither fair nor just" ("Gov. John Kitzhaber of Oregon declares a moratorium on all executions | Death Penalty Information Center,” 2011). As Governor Wolf articulated, if states are "going to take the irrevocable step of executing a human being, its capital sentencing system must be infallible." (Wolf, 2015). These governors, using their constitutionally-issued clemency powers, initiated these moratoriums as a way to prevent the injustice occurring within the capital system and act as a catalyst for their legislatures and citizens to consider and evaluate change. They have not suspended the law itself or changed the law without legislative approval. Instead they have only postponed the administration of these laws by deciding they will not sign any death warrant while in office. Furthermore, executives at both the state and federal level have, throughout the nation's history, have issued executive orders for political reasons. The political motive behind these reprieves does not invalidate these moratoriums or make them unconstitutional.

There similarly is a lack of historical foundation to suggest that these moratoriums are unconstitutional. The established understanding of a reprieve from English common law never suggested that a reprieve has been restricted. Moreover, nothing throughout the history of the United States has suggest that the president's power has been restricted when issuing forms of clemency like reprieves. There is further a lack of historical foundation to suggest that the states have restricted a governor's powers to issue clemency specifically with respect to reprieves. Moreover, these moratoriums are not unique to Oregon, Colorado, Washington, and Pennsylvania. Other governors from other states like Illinois, Maryland, and Tennessee have 
issued moratoriums on the death penalty (Smyler et al., 2015). These moratoriums were never deemed to be unconstitutional. Based on the established historical pattern, these moratoriums are not an overreach of gubernatorial clemency powers.

These moratoriums do not solve the problem of systemic injustice in America's capital punishment system, they instead act as a call to action to address these injustices. Moratoriums serve as a temporary pause so that the systemic problems of the death penalty can be investigated. Moratoriums like the ones instigated by these governors are intended to cause society to reevaluate the capital justice system within their state and within the nation. Though temporary, these moratoriums are well within the bounds of these governor's gubernatorial clemency powers. They are not the final answer to fixing the systemic problems present in the death penalty system, but they are a step towards addressing those problems. 


\section{$\underline{\text { References: }}$}

Atkins v. Virginia, 536 US 304 (Supreme Court 2002). Retrieved from https://scholar.google.com/scholar_case?case=2043469055777796288\&q=Atkins+v.+vir ginia\&hl=en\&as_sdt=6,38

Augé, K., Lee, K., \& Steffen, J. (2013, 22). Nathan Dunlap Granted “Temporary Reprieve” by Governor. Retrieved from https://www.denverpost.com/2013/05/22/nathan-dunlapgranted-temporary-reprieve-by-governor/

Baker v. Carr, 369 US 186 (Supreme Court 1962). Retrieved from https://scholar.google.com/scholar_case $?$ case $=6066081450900314197 \& q=$ baker+v.+carr \&hl=en\&as_sdt=6,38

Bessler, J. D. (2012). Chapter 5 The Eighth Amendment. In Cruel and Unusual: The American Death Penalty and the Founders' Eighth Amendment (pp. 162-221). Boston, Massachusetts: Northeastern University Press.

Buenviaje, D. E. (2010). The Death Penalty in the North. In G. M. Bakken (Ed.), Invitation to an Execution: A History of the Death Penalty in the United States of America (p. 467). United States of America: University of New Mexico Press.

Burns Jr., H. J., Eisenberg, R., McCann, E. F., \& Williams, R. S. (2015a). Commonwealth's Brief in Reply to Respondent Governor Tom Wolf.

Burns Jr., H. J., Eisenberg, R., McCann, E. F., \& Williams, R. S. (2015b). Commonwealth's Brief in Reply to Respondent Terrance Williams.

Burton, C. (2003). A Legislative History of the Oregon Constitution of 1857 - Part II (Frame of Government: Articles III-VII). Willamette Law Review, 39(245). Retrieved from http://www-lexisnexis- 
com.proxy.lib.pdx.edu/hottopics/lnacademic/?verb=sr\&csi=146173\&sr=TITLE(A+legisl ative+history+of+the+Oregon+Constitution+of+1857++part+II+frame+of+government+articles+IIIVII+)\%2BAND\%2BDATE\%2BIS\%2B2003

Chevigny, K., \& Johnson, K. (2004). Deadline. Big Mouth Productions.

Clemency | Definition of Clemency by Merriam-Webster Law Dictionary. (2018). Retrieved from https://www.merriam-webster.com/dictionary/clemency\#legalDictionary

Clemency Statistics | PARDON | Department of Justice. (2018). Retrieved from https://www.justice.gov/pardon/clemency-statistics

Cockerham, A. G., \& Crew, R. E. (2017). Factors Affecting Governors’ Decisions to Issue Executive Orders. State and Local Government Review, 49(1), 6-14. https://doi.org/10.1177/0160323X17702702

Coker v. Georgia, 433 US 584 (Supreme Court 1997). Retrieved from https://scholar.google.com/scholar_case?case=13789703704209593383\&q=coker+v.+ge orgia\&hl=en\&as_sdt=6,38

Commonwealth of Pennsylvania. v. Williams, 129 A. 3d 1199 (Supreme Court 2015). Retrieved from https://scholar.google.com/scholar_case?case=2216335863288173442\&q=Commonwealt h+v.+Williams+No.+14+em+2015\&hl=en\&as_sdt=4,39

Commutation | Definition of Commutation by Merriam-Webster Law Dictionary. (2018). Retrieved from https://www.merriam-webster.com/dictionary/commutation Comparing Federal \& State Courts. (2018). Retrieved from http://www.uscourts.gov/aboutfederal-courts/court-role-and-structure/comparing-federal-state-courts 
Corey, R. A., Mann, J. G., Dymek, T., Crompton, J. A., \& Gerdes, M. C. (2015). Brief for Amici Curiae the Speaker of the Pennsylvania House of Representatives and the President Pro Tempore of the Senate of Pennsylvania in Support of the Position of Petitioner Commonwealth of Pennsylvania.

Diament, M. (2010, October 5). Obama Signs Bill Replacing “Mental Retardation” with “Intellectual Disability." Retrieved from https://www.disabilityscoop.com/2010/10/05/obama-signs-rosas-law/10547

Duker, W. F. (1977). The President's Power to Pardon: A Constitutional History. WILLIAM AND MARY LAW REVIEW, 18, 65.

Eason, B., \& Frank, J. (2017, January 20). Colorado bill would repeal death penalty. Retrieved May 1, 2018, from https://www.denverpost.com/2017/01/19/colorado-bill-repeal-deathpenalty/

Emelda, M. (2017, October 25). Difference Between Commonwealth and State. Retrieved from www.differencebetween.net/miscellaneous/politics/difference-between-commonwealthand-state/

Ex parte Garland, 71 US 333 (Supreme Court 1866). Retrieved from https://scholar.google.com/scholar_case?case=2981583583221536357\&q=ex+parte+garl and\&hl=en\&as_sdt=6,38

Ex Parte Grossman, 267 US 87 (Supreme Court 1925). Retrieved from https://scholar.google.com/scholar_case?case $=15158969109722656375 \& q=e x+$ parte+gro ssman\&hl=en\&as_sdt $=6,38$

Federal Death Penalty | Death Penalty Information Center. (2018). Retrieved from https://deathpenaltyinfo.org/federal-death-penalty\#Background 
Furman v. Georgia, 408 US 238 (Supreme Court 1972). Retrieved from

https://scholar.google.com/scholar_case?case=3510234117314043073\&q=Furman+v.+ge orgia\&hl=en\&as_sdt=6,38

Gov. John Kitzhaber of Oregon declares a moratorium on all executions | Death Penalty Information Center. (2011). [Death Penalty Information Center]. Retrieved from https://deathpenaltyinfo.org/gov-john-kitzhaber-oregon-declares-moratorium-allexecutions

Gov. John Kitzhaber of Oregon declares a moratorium on all executions | Death Penalty Information Center. (n.d.). Retrieved from https://deathpenaltyinfo.org/gov-johnkitzhaber-oregon-declares-moratorium-all-executions

Greenleaf, S. J., Erickson, E., Pippy, J., White, D., Leach, D., Ferlo, J., ... Wozniak, J. Senate Resolution No. 6, Pub. L. No. 6 (2011). Retrieved from http://www.legis.state.pa.us/CFDOCS/Legis/PN/Public/btCheck.cfm?txtType=PDF\&sess Yr=2011\&sessInd=0\&billBody=S\&billTyp=R\&billNbr=0006\&pn=1833

Gregg v. Georgia, 428 US 153 (Supreme Court 1976). Retrieved from https://scholar.google.com/scholar_case?case=15950556903605745543\&q=gregg+v+geo rgia\&hl=en\&as_sdt=6,38

Hall, P. (2015, February 13). Pennsylvania Death penalty Moratorium Issued by Gov. Tom Wolf - The Morning Call. Retrieved from http://www.mcall.com/news/breaking/mc-pa-deathpenalty-moratorium-tom-wolf-20150213-story.html

Hamilton, A. (1788a). The Avalon Project: Federalist No 74. Retrieved from http://avalon.law.yale.edu/18th_century/fed74.asp 
Hamilton, A. (1788b, March 14). The Avalon Project: Federalist No 69. Retrieved from http://avalon.law.yale.edu/18th_century/fed69.asp

Haugen v. Kitzhaber, 306 P. 3d 592 (Supreme Court 2013). Retrieved from https://scholar.google.com/scholar_case case=5599786248648924186\&q=Haugen+v.+K itzhaber\&hl=en\&as_sdt=6,38

Hernandez, T. (2016, October 19). Brown to Maintain Death Penalty Moratorium. Retrieved from http://www.oregonlive.com/pacific-northwestnews/index.ssf/2016/10/brown_to_maintain_death_penalt.html

Herrera v. Collins, 506 US 390 (Supreme Court 1993).

Hickenlooper, G. J. W. (2013, May 22). Executive Order D 2013-006: Death Sentence Reprieve. Retrieved from https://test.colorado.gov/governor/sites/default/files/d_2013006_death_sentence_reprieve.pdf

Jung, H. (2011, November 22). Gov. John Kitzhaber Stops Executions in Oregon, Calls System “Compromised and Inequitable.” Retrieved from http://www.oregonlive.com/pacificnorthwest-news/index.ssf/2011/11/gov_john_kitzhaber_stops_all_e.html

Kaplan, A. B., Collins, P. A., \& Mayhew, V. L. (2016). Oregon's Death Penalty: A Cost Analysis. SSRN Electronic Journal. https://doi.org/10.2139/ssrn.2926131

Kennedy v. Louisiana, 554 US 407 (Supreme Court 2008). Retrieved from https://scholar.google.com/scholar_case?case=11619441780737591071\&q=Kennedy+v. +louisiana\&hl=en\&as_sdt=6,38

Kichline, M. L. (2015). Brief of Amicus Curiae the Pennsylvania District Attorneys Association in Support of Petitioner.

Konstan, D. (2005). Clemency as a Virtue. Classical Philology, 100(4), 337-346. 
Latto, H. (2012). Answering Brief on the Merits of Respondent Gary D. Haugen, 77.

Laythe, J. (2010). The Death Penalty in the Pacific Northwest. In G. M. Bakken (Ed.), Invitation to an Execution: A History of the Death Penalty in the United States (p. 467). United States of America: University of New Mexico Press.

Long, W. R. (2001). A Tortured History: The Story of Capital Punishment in Oregon. Eugene, Oregon: The Oregon Criminal Defense Lawyers Association.

Moratorium | Definition of Moratorium by Merriam-Webster Law Dictionary. (2018). Retrieved from https://www.merriam-webster.com/dictionary/moratorium

Murphy v. Ford, 390 F. Supp. 1372 (Dist. Court 1975). Retrieved from https://scholar.google.com/scholar_case $?$ case $=2743359122342916029 \& q=$ Murphy+v.+F ord\&hl=en\&as_sdt=6,38

Nolan, S., \& Kane, T. (2015). Brief of Respondent Terrance Williams.

Oregon | Death Penalty Information Center. (2018). Retrieved from https://deathpenaltyinfo.org/oregon-1

Oregon Department of Corrections. (2000). History of Capital Punishment in Oregon. Retrieved from http://www.oregon.gov/doc/OC/Pages/cap_punishment/history.aspx

Palombo, L., Glanville, K., Haberman, M., \& Hernandez, T. (2018). Oregon Death Row. Retrieved from http://www.oregonlive.com/pacific-northwestnews/index.ssf/page/oregon_death_row.html

Pardon | Definition of Pardon by Merriam-Webster Law Dictionary. (2018). Retrieved from https://www.merriam-webster.com/dictionary/pardon

Pennsylvania | Death Penalty Information Center. (2018). Retrieved from https://deathpenaltyinfo.org/pennsylvania-1 
Pennsylvania Board of Pardons. (2018). History of the Board of Pardons. Retrieved from http://www.bop.pa.gov/Pages/History.aspx

Pennsylvania Current Execution List. (2018). Retrieved from http://www.cor.pa.gov/sites/cor/Pages/PageNotFoundError.aspx?requestUrl=http://www. cor.pa.gov/

Post, A. (1944). Early Efforts to Abolish Capital Punishment in Pennsylvania. Pennsylvania Magazine of History and Biography, 68(1), 38-53.

Radelet, M. L. (2017). The History of the Death Penalty in Colorado. Boulder, Colorado: University Press of Colorado.

Reggle, M. H. (1997). Readings - History Of The Death Penalty | The Execution |FRONTLINE | PBS. Retrieved from https://www.pbs.org/wgbh/pages/frontline/shows/execution/readings/history.html Reprieve | Definition of Reprieve by Merriam-Webster Law Dictionary. (2018). Retrieved from https://www.merriam-webster.com/dictionary/reprieve

Roper v. Simmons, 543 US 551 (Supreme Court 2005). Retrieved from https://scholar.google.com/scholar_case?case=16987406842050815187\&q=roper+v.+sim mons\&hl=en\&as_sdt=6,38

Rosenblum, E. F., Joyce, A. M., \& Hogue, J. (2012). Brief on the Merits of Appellant, John Kitzhaber, Governor of the State of Oregon, 30.

Rosenblum, E. F., Joyce, A. M., \& Hogue, J. (2013). Reply Brief, 13.

Sarasohn, D. (2018, April 19). John Kitzhaber (1947 - ). Retrieved from https://oregonencyclopedia.org/articles/kitzhaber_john_1947_/\#.WwXGgHrwbcs 
Scherer, B. F. (1994). The Supreme Court of Pennsylvania and the Origins of King's Bench Power. Duquesne Law Review, 32(525).

Smith, J. (2014, February 11). Gov. Jay Inslee announces capital punishment moratorium | Governor Jay Inslee. Retrieved March 27, 2018, from https://www.governor.wa.gov/news-media/gov-jay-inslee-announces-capital-punishmentmoratorium

Smyler, D. J., Moulton Jr., H. G., Lehr, M. G. Z., \& Concannon, S. M. (2015). Brief of Respondent Governor Tom Wolf.

State of Washington Office of the Governor. (2014). Governor Inslee's remarks announcing a capital punishment moratorium. Retrieved from https://www.governor.wa.gov/sites/default/files/documents/20140211_death_penalty_mo ratorium.pdf

States with and Without the Death Penalty | Death Penalty Information Center. (2018). Retrieved from https://deathpenaltyinfo.org/states-and-without-death-penalty

Trop v. Dulles, 356 US 86 (Supreme Court 1958). Retrieved from https://scholar.google.com/scholar_case?case $=8267310144688717588 \& q=$ trop+v+dulles \&hl=en\&as_sdt $=6,38$

United States v. Klein, 80 US 128 (Supreme Court 1872). Retrieved from https://scholar.google.com/scholar_case $?$ case $=6707068617171100568 \& q=$ united+states+ v.+klein\&hl=en\&as_sdt $=6,38$

Washington | Death Penalty Information Center. (2018). Retrieved from https://deathpenaltyinfo.org/washington-1\#history 
Wasserman, M. (2018, February 14). Abolition of death penalty gets closer to reality as bill clears Washington state Senate. Retrieved from http://www.thenewstribune.com/news/local/article200182509.html

Weems v. United States, 217 US 349 (Supreme Court 1910). Retrieved from https://scholar.google.com/scholar_case?case=8944369929987696113\&q=weems+v+uni ted+states\&hl=en\&as_sdt=6,38

Wilgoren, J. (2003, January 12). Citing Issue of Fairness, Governor Clears Out Death Row in Illinois. The New York Times. Retrieved from https://www.nytimes.com/2003/01/12/us/citing-issue-of-fairness-governor-clears-outdeath-row-in-illinois.html

Wolf, G. T. (2015). Death Penalty Moratorium Declaration Memorandum. Retrieved from https://www.scribd.com/doc/255668788/Death-Penalty-Moratorium-Declaration 